\title{
THE THEORY, HISTORY, AND PRACTICE OF THE BRIBERY-EXTORTION DISTINCTION
}

\section{JAMES LINDGREN $\dagger$}

In the law of blackmail and extortion, two topics have generated great debates: the paradox of blackmail and the bribery-extortion distinction. The paradox debate has so far been more theoretical than practical or historical, while the bribery-extortion debate has been more practical and historical than theoretical. In this Article, I will first examine the theoretical overlap of bribery and extortion. Next, I will try to tie together the paradox debate and the briberyextortion debate. As I see it, the same principle that underlies bribery underlies public official extortion and blackmail. That is part of what has made extortion and bribery so difficult to distinguish. Then I will analyze the recent Supreme Court jurisprudence of extortion and answer some of the historical questions raised by the sharp exchange between Justices Stevens and Thomas over my work.

\section{THE THEORY OF THE BRIBERY-EXTORTION DISTINCTION}

\section{A. The Definitions of Bribery and Extortion}

Extortion is of two types: extortion by threats or fear and extortion under color of office. Extortion by threats or fear (coercive extortion) can refer to any illegal use of a threat or fear to obtain property or advantages from another, short of violence that would be robbery. ${ }^{1}$ Statutes usually set out the kinds of threats or

† Norman \& Edna Freehling Scholar, Associate Dean for Faculty Development, and Professor of Law, Chicago-Kent College of Law. B.A., 1974, Yale University; J.D., 1977, University of Chicago. I must thank many people for stimulating my thinking on this issue over the years, including Philip Hamburger, Franklin Zimring, Ronald Coase, Randy Block, Leo Katz, Ronald Allen, Bill Marshall, Peter Low, Wendy Gordon, Lori Andrews, Daniel Lowenstein, and David Burgess. I would particularly like to thank Colin Diver, Leo Katz, and the editors of the University of Pennsylvania Law Review for providing a warm home for this Symposium. Much of this paper was written during the winter and spring of 1992, while I was a Visiting Scholar at the Northwestern University and University of Chicago Law Schools. I would like to thank both schools and their deans for their generous support of this project, as well as the Marshall D. Ewell Fund of Chicago-Kent College of Law. A portion of part I appeared previously in the UCLA Law Review.

1 See, e.g., Proposed Penal Code Of THE State of New York § 614 (1865) [hereinafter FIELD CODE] ("What threats may constitute extortion"); MODEL PENAL 
fear that make up extortion-for example, the threat to commit a crime, injure person or property, expose a crime, or expose contemptible information. ${ }^{2}$ Coercive extortion is often called blackmail, particularly where hush money is involved, but few blackmail statutes remain on the books. Usually, blackmail behavior is covered under extortion, theft, or coercion statutes. ${ }^{3}$ If public officials or threats of physical violence are involved, the term extortion is more commonly used than blackmail in ordinary speech.

The debate over the bribery-extortion distinction has centered on the second type of extortion-extortion under color of office. Historically, extortion under color of office is the seeking or receipt of a corrupt payment by a public official (or a pretended public official) because of his office or his ability to influence official action. ${ }^{4}$ Bribery is a corrupt benefit given or received to influence official action. ${ }^{5}$

In England and the United States, the primary public corruption offense over most of the last 700 years has been extortion, though in recent years bribery prosecutions appear to be at least as common. As an offense called bribery, this crime probably appeared relatively late (mid-1500s) ${ }^{6}$ and may not have been routinely applied to administrative officials until the $1800 \mathrm{~s}^{7}$

CODE $\$ 223.4$ (1962) (defining theft by extortion).

2 See James Lindgren, Unraveling the Paradox of Blackmail, 84 Colum L. REv. 670, 673 \& nn.20-22 (1984) (giving examples of the most commonly prohibited threats).

${ }^{3}$ See, e.g., ALA. CODE \$ 13A-6-25 (1982) (coercion); ALASKA STAT. \$11.41.530 (1989) (coercion); ARK. CODE ANN. § 5-13-208 (Michie 1987) (coercion); id. §§ 5-36102 to -103 (Michie 1987 \& Supp. 1991) (theft); CoNN. GEN. STAT. ANN. § 53a-192 (West 1985) (coercion); ILL. ANN. STAT. ch. 38, para. 16-1 (Smith-Hurd 1977 \& Supp. 1992) (theft); N.J. STAT. ANN. § 2C:13-5 (West 1982) (coercion); N.Y. PENAL LAW \$ 135.60 (McKinney 1987) (coercion); N.D. CENT. CODE § 12.1-17-06 (1985) (coercion); OHIO REV. CODE ANN. § 2905.12 (Anderson 1987) (coercion); S.D. CoDified LAwS ANN. § 22-30A-4 (1988) (theft); MODEL PENAL CODE § 223.4 (1962) (theft by extortion); id. $\$ 212.5$ (criminal coercion).

4 See James Lindgren, The Elusive Distinction Between Bribery and Extortion: From the Common Law to the Hobbs Act, 35 UCLA L. REv. 815, 825 (1988).

${ }^{5} \mathrm{See}$ id. at 824. In lay terms, the influence is in one direction: to afford the giver better than fair treatment.

${ }^{6}$ Noonan's account of bribery is completely unclear about when the crime of bribery arose in England. See JOHN T. NOONAN, JR., BRIBES (1984) (providing a history of bribery-type offenses from 3000 B.C. to 1984). References to bribery cases in Star Chamber records start appearing in about 1550. See id. at 315.

${ }^{7}$ Noonan counts the impeachment of Warren Hastings, an eighteenth century governor of the British colony of Bengal, India, as the first clear administrative bribery case, but it's really an extortion case. See id. at 392-424, 579 (giving a biography of Warren Hastings and describing the acts that led to his impeachment 
Obviously, there was always a need to punish bribery-type behavior by public officials. Continuously since the 1200 s, extortion has met that need.

One sees much the same kind of public corruption case in the late 1200 s as in modern cases in the federal courts. Then, as now, extortion has usually embraced takings by coercion, false pretenses, or bribery. ${ }^{8}$ Bribery and extortion substantially overlap and have for centuries. In the late nineteenth century and the first half of the twentieth century, many American courts attempted to separate the two crimes, sometimes even claiming that the two crimes were mutually exclusive. ${ }^{9}$ Nonetheless, even during this period, there remained a substantial line of cases, consistent with the earlier and later cases, holding that the two crimes could be committed on the same facts-indeed, even affirming bribery and extortion convictions for the same transaction. ${ }^{10}$ Under modern Hobbs Act ${ }^{11}$ jurisprudence, the overlap has been baldly admitted: "extortion 'under color of official right' equals the knowing receipt of bribes."12

trial). I am in some doubt on this point because I found one 1600 case involving a constable that appears to be a bribery case, but the report may just be describing the behavior rather than the crime. See Rigge (1600), in YORKSHIRE ARCHAEOLOGICAL AND TOPOGRAPHICAI ASS'N, 3 RECORD SERIES, 2 WEST RIDING SESSIONS ROLLS 1597. 1602, at 207 (J. Lister ed. 1888) (stating that constable "levied more soldiers for musters than were required, and after by the way agreed with some of them for bribes and turned the men home again").

8 See Lindgren, supra note 4, at 848-62.

${ }^{9}$ See People v. Feld, 28 N.Y.S.2d 796, 797-98 (App. Div. 1941) (holding that bribery of a labor official and coercive extortion are mutually exclusive; official right extortion wasn't under prosecution).

${ }^{10}$ See Martin v. United States, 278 F. 913 (2d Cir. 1922) (involving visa officer convicted of both bribery and official extortion for taking $\$ 30$ "grease" payment to speed up processing); State v. Vallee, 12 A.2d 421 (Me. 1940) (holding shakedown of public janitor by county commissioner to be both extortion by fear and bribery); People v. Hansen, 150 N.E. 542 (N.Y. 1925) (per curiam) (upholding convictions for both bribery and extortion under color of official right on the same facts, despite defendant's argument that the two crimes were mutually exclusive).

11 See 18 U.S.C. \$1951 (1988).

12 United States v. Holzer, 840 F.2d 1343, 1351 (7th Cir.), cert. denied, 486 U.S. 1035 (1988). See United States v. Butler, 618 F.2d 411, 418 (6th Cir.) ("[A] showing that the motivation for the payment focuses on the recipient's office, regardless of who induces the payments, is sufficient to convict under the Hobbs Act."), cert. denied, 447 U.S. 927 (1980); United States v. Braasch, 505 F.2d 139, 151 (7th Cir. 1974) ("So long as the motivation for the payment focuses on the recipient's office, the conduct falls within the ambit of [the Hobbs Act]."), cert. denied, 421 U.S. 910 (1975); see also Christine Dibble, Note, Reevaluating the Application of the Hobbs Act to Public Officials, 3 J.L. POL. 387, 395 (1986) (noting that courts have found that bribery "cannot successfully be asserted as a defense to a Hobbs Act charge"); James P. Fleissner, Comment, Prosecuting Public Officials Under the Hobbs Act: Inducement as an Element of 
This old common law tradition has been recently adopted by the United States Supreme Court in Evans v. United States. ${ }^{13}$

A persistent question remains: What is the difference between bribery and extortion? I will try to distinguish the terms in ordinary speech. Nonlawyers tend to think of extortion as necessarily coercive. Thus I will first try to distinguish bribery from coercive extortion by public officials.

\section{B. The Ordinary-Language Distinction Between Bribery and Coercive Extortion}

\section{Refining the Lay Definitions}

First, when a briber corruptly pays off a public official, he is paying to get some result for himself or those he favors. $\mathrm{He}$ is seeking preferential treatment. This preference may be substantialfor example, changing a losing bidder into a winner. Or it may be slight-for example, increasing the chances that a probably meritorious bidder will win. Nevertheless, a briber is not just paying to influence official behavior, he is paying to influence action in his favor. ${ }^{14}$

Second, even someone who is paying to influence official behavior in his favor may not be acting corruptly if he is merely buying back fair treatment from an official who threatens to inflict unfair treatment. Although the morality of giving in to a coercive extortion threat has been debated for centuries, ${ }^{15}$ capitulating is often not illegal. ${ }^{16}$ Many people would not consider it bribery for

Extortion Under Color of Official Right, 52 U. CHI. L. REv. 1066, 1073-74 (1985) ("The mere acceptance of an unsolicited bribe constitutes extortion under color of official right."); Note, Limiting Expansion into Public Corruption Under the Hobbs Act: United States v. O'Grady, 18 CoNN. L. REv. 183, 185-90 (1985).

13 See Evans v. United States, 112 S. Ct. 1881 (1992).

14 See, e.g., Daniel H. Lowenstein, Political Bribery and the Intermediate Theory of Politics, 32 UCLA L. REV. 784, 825 (1985) ("The briber influences the official if the gift increases the probability that the official will act as the briber hopes.").

15 See, e.g., RICHARD BAXTER, A CHRISTIAN DIRECTORY, OR A SUMMA OF Practical THEOlogie, AND CASES Of CoNSCIENCE 4, 116 (1673), quoted in NoONAN, supra note 6, at 388-89; 3 PIERRE LE CHANTRE, SUMMA DE SACRAMENTIS ET ANIMAE CoNSILIIS 2a, 3, 35-36 (Jean-Albert Duguaquier ed., 1954) (late 12th century), quoted in NOONAN, supra note 6, at 176.

16 The Model Penal Code, however, makes it bribery to capitulate to an extortion threat. See MODEL PENAL CODE $\$ 240.1$ (1962) (defining bribery in official and political matters); MODEL PENAL CODE AND COMMENTARIES $\$ 240.1 \mathrm{cmt} .2$ (1980) (discussing omission of word "corrupt" from the definition of bribery); $i d$. at cmt. 10 (discussing denial of the extortion defense to bribery). 
a citizen to pay off a public official who is forcing the citizen to buy back what ought to be his for free. ${ }^{17}$ If a citizen is paying only to buy fair treatment and nothing more, he is the victim of extortion and has not committed bribery according to its general lay conception. Bribery usually is thought to consist of paying for better than fair treatment.

Thus, the lay definition of bribery can be restated: bribery is a corrupt benefit given or received to influence official action so as to afford the giver better than fair treatment. Both the person giving and the person receiving the benefit are guilty of bribery. ${ }^{18}$ And, indeed, this reciprocity is a characteristic of most bribery situations. When bribery occurs, the payor usually makes a payment that is corrupt for him to make. Such a corrupt payment is one that unfairly distorts official decisionmaking. Because people don't pay unless they expect to get something they want, the distortion will almost invariably be in favor of the payor or his friends. Thus, unless the payor is trying to gain an unfair advantage, he is usually viewed as the victim of official extortion and is not considered guilty of bribery.

In my view, coercive extortion by a public official is the seeking or receiving of a corrupt benefit paid under an implicit or explicit threat to give the payor worse than fair treatment or to make the payor worse off than he is now or worse than he expects to be. The payee is guilty of extortion; the payor is the victim of extortion. This kind of coercion constitutes the modern lay conception of extortion by public officials. Thus, while bribery has only one baseline (fair treatment), coercive extortion has at least three baselines (fair treatment, expected treatment, and the status quo).

17 However, if the payor is paying to fix a case, for example, the relevant question is not whether he would have won his case, but whether he is paying for more than fair treatment. If he is paying the judge or public official to win his case whatever the merits might be-to make a probability of victory into a certainty-it would still be a corrupt payment for both the payor and the public official. On the morality of buying back what ought to be yours for free, see NOONAN, supra note 6, at 176 (reporting that, in 1191-1192, Le Chantre asked whether one may morally buy back a right but that he does not answer the question; instead he suggests that an exemplary man would refuse to capitulate); see also id. at 178-79 (reporting that Thomas of Chobham in the early thirteenth century wrote that it's not sinful "to buy back one's own right from a judge when one cannot otherwise have it" and that a litigant receives "nothing from the judge except what is his own or what is owed to him.").

${ }^{18}$ See Rex v. Vaughan, 98 Eng. Rep. 308, 311 (K.B. 1769) (Mansfield, L.) ("Wherever it is a crime to take, it is a crime to give: they are reciprocal."). 
For example, it's extortion if a public official threatens to deny a public contract to a bidding contractor who clearly deserves to receive it unless the bidder pays off the official. The official would receive the payoff under a threat to give the contractor worse than fair treatment. The contractor would not have done anything wrong since he was forced to buy back only what he deserved in the first place. On the other hand, it would be bribery if a clearly unqualified contractor paid off the official to get the contract. Here, the contractor would be paying to get better than fair treatment. Thus he, along with the public official, would be guilty of bribery. Situations like this are on the minds of the public when the words "bribery" and "extortion" are used.

\section{The Overlap of Bribery and Coercive Extortion} by Public Officials

Even as I have stated their lay conceptions, bribery and extortion overlap. In most payoff situations, we won't clearly know who actually deserved to get a public contract. ${ }^{19}$ Usually, the official makes the bidder aware that he won't get the contract unless he pays off the official, and if the bidder pays, he will definitely get the contract. Fair treatment would consist of the bidder being given a fair chance against all other bidders, but that is usually not a realistic option in payoff cases. If the bidder doesn't pay, he gets less than fair treatment (coercive extortion). If he pays, he gets more than fair treatment (bribery). Thus the same envelope filled with cash can be both a payment extorted under a threat of unfairly negative treatment and a bribe obtained under a promise of unfairly positive treatment. This is one common situation where bribery and extortion overlap, even if one limits extortion only to its lay conception as coercion. Unless a legislature clearly indicates otherwise, there is no reason to let off a briber just because he was also a victim of extortion. If we were to let the briber off, he could continue to cheat the public and other bidders, safe in the knowl-

19 The forms of pressure are subtle. See Charles F.C. Ruff, Federal Prosecution of Local Corruption: A Case Study in the Making of Law Enforcement Policy, 65 GEO. L.J. 1171,1177 (1977) (stating that "prosecutors . . . encountered a level of sophistication in the making and receiving of illicit payments which promised substantial difficulty in establishing the commission of extortion by duress"); Herbert J. Stern, Prosecutions of Local Political Corruption Under the Hobbs Act: The Unnecessary Distinction Between Bribery and Extortion, 3 SETON HALL L. REv. 1, 6 (1971) (noting that "a local official may not even need to solicit the kickback, much less demand it ${ }^{n}$ ) (emphasis omitted). 
edge that the official was corrupt enough to refuse him a fair chance without a payoff. ${ }^{20}$

A second common situation where bribery and coercive extortion overlap is where a public official explicitly or implicitly threatens to make the victim worse off than she is now, but no worse than the victim deserves to be. I can illustrate this situation best by starting with coercive extortion by private citizens. It's extortion if a private citizen threatens to have a criminal arrested unless the criminal pays hush money to the private citizen. This is true even though the criminal is paying to avoid a harm that arguably deserves to be inflicted on her-arrest.

It's also extortion if the citizen has a legal duty to turn in the criminal. For instance, under federal law we all have a duty to report people who commit federal felonies. ${ }^{21}$ Yet it would still be extortion for a private citizen to threaten to report a federal felon unless he is paid off, despite the threatener's breach of his legal duty to report. ${ }^{22}$

Now what about government officials who have a duty to arrest criminals? Here coercive extortion and bribery overlap. If a police officer suggests that he will not arrest a criminal if he is paid off, this is extortion, ${ }^{23}$ because he is threatening to make the criminal worse off than he is now. But it's also bribery, ${ }^{24}$ because the criminal is paying hush money for more than fair treatment. Police officers who take protection or hush money from drug dealers, liquor law violators, or prostitutes commit extortion just as much as a private citizen would for taking the same protection money. Yet it's classic bribery for public officials to take routine payments not

20 The threat of the loss of a contract would usually not be sufficient duress to exculpate a defendant from criminal liability under the general principles of the duress defense. See, e.g., MODEL PENAL CODE $\$ 2.09$ (1962) (defining the affirmative defense of duress).

2118 U.S.C. $\S 4$ (1988) (misprision of felony).

22 See United States v. Smith, 228 F. Supp. 345, 348 (E.D. La. 1964) (holding that a threat to expose a company's fraud on government contracts, a federal felony, unless the company rehired specific persons is sufficient to indict defendant for blackmail).

${ }^{23}$ See, e.g., United States v. Braasch, 505 F.2d 139, 151 (7th Cir. 1974), cert. denied, 421 U.S. 910 (1975) (holding defendant police officers guilty of extortion for "taking money to refrain from their duties"); Ellwyn R. Stoddard, Blue-Coat Crime, in 2 CRIMB \& JustiCE 194 (Leon Radzinowicz \& Marvin E. Wolfgang eds., 1971) (defining extortion).

24 See 11 C.J.S. Bribery $\S 2 \mathrm{e}(3)$ (1938) ("[R]eceipt by an authorized officer, of a bribe to release one from arrest is criminal without regard to the legality of the arrest."); Stoddard, supra note 23 (defining bribery). 
to enforce the law. Indeed, if a police officer suggested to a prostitute that he might forget about arresting her if she paid him off every week, it would be difficult to say if it would be more common to characterize the behavior ${ }^{25}$ as extortion or the solicitation of a bribe.

A related situation of overlap is in the bribery of a witness. Assume that a potential witness offers not to testify about a crime if paid off or, to state it differently, threatens to testify unless paid off. If an accused criminal pays to suppress the testimony, the potential witness has committed both extortion and bribery. He has committed coercive extortion by threatening to make the criminal worse off than he is now (but no worse than the criminal deserves to be). He has committed bribery since he has accepted a payment that will give the payor more than fair treatment. A good example of this situation is Howard Hunt's request for large sums of money to keep quiet about Watergate. Judge John Noonan in his book, Bribes, calls this behavior bribery, ${ }^{26}$ but Nixon and most writers at the time called it blackmail, ${ }^{27}$ a synonym for extortion.

\section{The Voluntary-Coercive Distinction and the Initiation-Passive Receipt Distinction}

A myriad of other distinctions have been offered for the difference between bribery and extortion. None of these have been clearly worked out in a way that would allow sustained analysis. Some of these beliefs are widely held by the general public and by academics, but they usually collapse when applied to particular situations.

None of the simplistic distinctions that might spring to mind can adequately capture the subtleties of the situation or keep bribery and extortion separate. First, one can't say that extortion is initiated by the public official, while bribery is initiated by the citizen. A public official may initiate bribery if he anticipates that the citizen would be willing to pay to get unwarranted public

25 See, e.g., Stoddard, supra note 23 (defining types of police misbehavior: (1) extortion as "street courts' where minor traffic tickets can be avoided by the payment of cash bail to the arresting officer with no receipt required," and (2) bribery as "[t]he payments of cash or 'gifts' for past or future assistance to avoid prosecution").

26 See NoONAN, supra note 6 , at 583 ("Bribery was ... at the core of the hard evidence set out against him [Nixon].").

27 See, e.g., THEODORE H. WHTTE, BREACH OF FAITH: THE FALl OF RICHARD NIXON 198-99, 200, 203, 326 (1975); BOB WOODWARD \& CARL BERNSTEIN, THE FINAL DAYS 50, 56, 89-92 (1976). 
benefits. This initiation is what is meant by the crime of "soliciting a bribe, ${ }^{28}$ where the public official almost invariably takes the first step. Many, if not most, bribery statutes punish the asking for a bribe as bribery or attempted bribery. Indeed, in the most copied nineteenth century criminal code, the 1881 New York Field Code, the method of taking for extortion under color of official right was the same as for bribery-asking, receiving, or agreeing to receive. ${ }^{29}$ Nor is extortion always initiated by the official. Even if extortion were limited to coercion (which it isn't), a citizen may begin discussing extortion if she correctly anticipates that she can't get fair treatment without making a payoff.

Another distinction that fails is the claim that extortion is coercive while bribery is voluntary. Since early common law, extortion by public officials has included receiving unwarranted payments-whether by coercion, false pretenses, or bribery. ${ }^{30}$ But even if we limited extortion to coercive extortion, the distinction wouldn't completely separate the two crimes. Their overlap is best illustrated by the examples raised earlier. If a private citizen takes hush money from a prostitute, she commits extortion, which is considered coercive. If, however, a public official takes hush money from the same prostitute, he commits bribery as well as extortion. Does the prostitute pay the public official voluntarily while she pays

28 See, e.g., Dixson v. United States, 465 U.S. 482,485 (1984) (stating that petitioners sought bribes and used their positions to "extract ... [money] in kickbacks"; therefore, they are guilty of violating the federal bribery statute); United States v. Benedetto, 571 F.2d 1246, 1247 (2d Cir. 1978) (affirming conviction of meat inspector for receiving money; case assumes that a bribe could be solicited); In re Bloom, 561 P.2d 258, 261 (Cal. 1977) (holding that the defendant's "solicitation of a . . . bribe for purposes of personal gain . . . shows he was . . . unfit to practice law" $)$; People v. Fujita, 43 Cal. Ct. App. 3d 454 (1974) (defendants acquitted of solicitation of bribery), cert. denied, 421 U.S. 964 (1975); Englander v. State, 246 So. $2 d$ 746, 747 (Fla.) (defendant charged with conspiracy to solicit a bribe and soliciting a bribe), cert. denied, 404 U.S. 858 (1971); In re Gottlieb, 486 N.E.2d 921, 922 (Ill. 1985) (denying reinstatement to attorney after disbarment following payments to state officials who solicited bribes); In re Holovachka, 198 N.E.2d 381, 391 (Ind. 1964) (stating that defendant "attempted to solicit a bribe from a local official"), cert. denied, 379 U.S. 974 (1965); Commonwealth v. Beneficial Fin. Co., 275 N.E.2d 33, 42 (Mass. 1971) (involving defendants charged with numerous offenses in connection with the solicitation of numerous bribes), cert. denied, 407 U.S. 910 (1972).

${ }^{29}$ Compare N.Y. PENAL LAW \$ 557 (1881) (extortion: "asks, or receives, or agrees to receive") with id. $\S 45$ ("[a]n executive officer . . . who asks, receives, or agrees to receive any bribe"); and $i d . \$ 67$ ("member of ... the legislature of this state, who asks, receives, or agrees to receive any bribe"); and id. $\$ 72$ ("judicial officer ... who asks, receives, or agrees to receive a bribe").

${ }^{30}$ See Lindgren, supra note 4, at 838-905 (explaining the evolution of extortion). 
the citizen only under coercion? The prostitute's fear would seem to be the same in both cases-exposure and prosecution. It's true that the official would be breaching his duty to enforce the law, but this doesn't make the payment any less coercive to the prostitute. And as I have pointed out earlier, the citizen may also be breaching her legal duty to report the prostitute. ${ }^{31}$ Whether a threat to enforce the law is coercive doesn't depend on the legal duty of the threatener.

\section{WHAT MAKES BRIBERY CORRUPT?}

A look at the first English bribery statute and the first English extortion statute show them to have the same idea at bottom-and on top as well. According to the first English statute that was later considered to be a bribery statute, judges may not take any "robe, fee, pension, gift, nor reward of any but the King, except reward of meat and drink, which shall be no great value." 32 It was in force from 1384 through 1881 . This statute's language is similar to the First Statute of Westminster, the main English extortion statute from 1275 through 1968. Among its many extortion provisions, Westminster I provided: "no Sheriff, or other officer of the King, shall take any Reward to do his Office, but shall be paid of what he takes of the King. ${ }^{n 33}$ The language is almost identical, the chief difference being the kind of officer covered. As these early statutes illustrate, the wrong of both crimes was then clearly focused on the acquisitive uses that can be put to state power, rather than the distortion of official decisionmaking.

Bribery is corrupt for two reasons: (1) it involves a public official using his office to gain advantages from citizens; and (2) it often distorts the underlying official action. The second concern may be secondary in importance as well. First, although there is some disagreement, bribery may be committed even where the official takes the proper official action, because he has used his office improperly for personal gain. Judge John Noonan even cites

\footnotetext{
${ }^{31}$ See supra notes $21-22$ and accompanying text.

328 Rich. 2, c. 3 (1384), (repealed by the Statute Law Revision Act, 44 \& 45 Vict., c. 59 (1881)) (based on 18 Edw. 3, stat. 4 (1344) (oath of justices)); see also 3 ENG. HIST. Doc. 869 (H. Rothwell ed., 1975) (Royal Proclamation of Oct. 20, 1258).

${ }^{33}$ Statute of Westminster I, 3 Edw. 1, c. 26 (1275) (translated from the Latin by author) (repealed by Theft Act, 1968, c. 60, \$ 33(3), sched. 3, and Statute Law Reform Act, 26 \& 27 Vict., c. 125 (1863)); Lindgren, supra note 4, at 841-48 (discussing origins of statute and its other extortion provisions).
} 
two literary examples where an official is "double-damned because he takes a bribe and does not act upon it. ${ }^{\text {n4 }}$ Second, as just illustrated, bribery arose as an offense in English law primarily in contexts suggesting concern for how officials acquire wealth. ${ }^{35}$ The concern seemed to be greedy officials, rather than powerful subjects distorting government.

Standard moral and economic accounts of the theory of bribery argue that it's a misuse of agency. In Corruption, Susan RoseAckerman sees legislators as agents for plural principals who take bribes to advance their self-interest at the possible expense of the interests of their principals. ${ }^{36}$ In Bribes, Judge Noonan argues:

The notion of fidelity in office, as old as Cicero, is inextricably bound to the concept of public interest distinct from private advantage. It is beyond debate that officials of the government are relied upon to act for the public interest not their own enrichment.

$\ldots$

When government officials act to enrich themselves they act against the fabric on which they depend, for what else does government rest upon except the expectation that those chosen to act for the public welfare will serve that welfare? ${ }^{37}$

Thus, the exploitation of public power for personal gain is an important justification for a law against bribery. An official accepting a bribe is using public leverage, the leverage of the government or the public, to make deals for his personal benefit. This is the same principle that I have identified as underlying blackmail. I have argued:

Let us first examine informational blackmail. Here the blackmailer threatens to tell others damaging information about the blackmail victim unless the victim heeds the blackmailer's request, usually a request for money. The blackmailer obtains what he wants by using extra leverage. But that leverage belongs more to a third person than to the blackmailer. The blackmail victim pays the blackmailer to avoid involving third parties; he

34 NOONAN, supra note 6, at 697 (citing Angelo in MEASURE FOR MEASURE and Hog in Cicero's literary classic).

${ }^{35}$ See Lindgren, supra note 4, at 873-75.

${ }^{36}$ See SUSAN ROSE-ACKERMAN, CORRUPTION: A STUdY IN POLITICAL ECONOMY 211 (1978) (noting that "[t]he problem of corruption . . . indicates that competition of self-interested actors may ... be used to subvert democratic processes and prevent the implementation of legislative decisions").

${ }^{37}$ NOONAN, supra note 6, at 704. 
pays to avoid being harmed by persons other than the blackmailer. When the reputation of a person is damaged, he is punished by all those who change their opinion of him. They may "punish" him by treating him differently or he may be punished merely by the knowledge that others no longer respect him.

Thus when a blackmailer threatens to turn in a criminal unless paid money, the blackmailer is bargaining with the state's chip. The blackmail victim pays to avoid the harm that the state would inflict; he pays because he believes that he can thereby suppress the state's potential criminal claim. Of course, this does not effect a legally binding settlement, but the leverage is effective precisely to the extent that the victim believes that he has reached an effective settlement. Likewise, when a blackmailer threatens to expose damaging but noncriminal behavior unless paid money, he is also turning third-party leverage to his own benefit. What makes his conduct blackmail is that he interposes himself parasitically in an actual or potential dispute in which he lacks a sufficiently direct interest. What right has he to make money by settling other people's claims?

At the heart of blackmail, then, is the triangular nature of the transaction, and particularly this disjunction between the blackmailer's personal benefit and the interests of the third parties whose leverage he uses. In effect, the blackmailer attempts to gain an advantage in return for suppressing someone else's actual or potential interest. The blackmailer is negotiating for his own gain with someone else's leverage or bargaining chips.

This misuse of another's leverage is perhaps seen most clearly in noninformational blackmail, in situations where a formal agency relationship exists-for instance, where a labor union leader threatens to cause a strike unless he is given a personal payoff. There the labor leader is turning group power and a group dispute to personal benefit. The pressure on the blackmail victim would be the same if the blackmailer's agency relationship were merely informal-for instance, where an influential businessman threatens to cause a strike unless he is given a personal payoff. Notice that the victim of blackmail probably does not care whether the threatener is a labor leader or an influential businessman, an authorized agent or an unauthorized one. What the victim fears is a strike. Whoever seelss a personal payoff by credibly wielding the power of a third party to harm the victim is a blackmailer.

The same misuse of representative or agency power can be seen where someone threatens to deny a public contract unless the contractor makes a payoff. Again, it doesn't matter much to the victim whether the threatener is a government official or an influential citizen, a formal representative or an informal one. 
Both would be turning group power to personal benefit, offering to suppress a potential interest of the government and the public for personal gain.

What emerges from these examples is the observation that blackmail is the misuse of an informal (or formal) power of agency or representation. Under my theory, blackmail is the seeking of an advantage by threatening to press an actual or potential dispute that is primarily between the blackmail victim and someone else. The blackmailer threatens to bring others into the dispute but typically asks for something for himself; he turns someone else's power, usually group power, to personal benefit. The bargaining is unfair in that the threatener uses leverage that is less his than someone else's. ${ }^{38}$

My theory has been correctly identified as an exploitation theory. ${ }^{39}$ This same theory of exploiting other people's interests for personal gain probably underlies other controversial areas of law besides blackmail and bribery-including payola (disc jockeys receiving personal payoffs to influence their decisions in ways that may not benefit their employers or audiences), insider trading (private information used for personal gain that must be used, if at all, after disclosure to the general public), and commercial bribery (purchasing agents or other company officials use company leverage for personal gain).

All of these areas-bribery, blackmail, payola, insider trading, and commercial bribery-share problems of determining underlying entitlements to the leverage being used. For example, if a legislator agrees in part in return for a large campaign contribution that he will choose a chief of staff that the contributor can work with, has he used public leverage for personal benefit? Or is the choice of a chief of staff personal enough (even though the staffer is on the government payroll) that it wouldn't be bribery (or extortion) to make the promise to the contributor?

It's notoriously difficult to separate bribery (or extortion) from gifts, tips, campaign contributions, and log-rolling. ${ }^{40}$ That one doesn't have a good theory to explain the entitlements isn't a refutation of either of the important principles underlying briberythat bribery is based on exploiting other people's leverage and that

${ }^{38}$ Lindgren, supra note 2, at 702-03 (emphasis and citations omitted).

${ }^{39}$ See Joel Feinberg, THE MORAL Limiss of the Criminal LaW: Harmless WRONGDOING 239-40 (1988) (defining theory as an "exploitation principle").

${ }^{40}$ See NoONAN, supra note 6 , at 687.90 (arguing that it is impossible, in many instances, to distinguish a bribe from a gift, tip, or campaign contribution). 
the line between corrupt and noncorrupt bargains should be drawn according to the degree to which there is a disjunction between individual benefit and group leverage.

\section{RECENT SUPREME COURT EXTORTION CASES: MCCORMICK AND EVANS}

After nearly two decades of dodging federal Hobbs Act extortion cases, the United States Supreme Court has finally taken up some of the issues that have created splits between the circuits. First, in McCormick v. United States, ${ }^{41}$ the Supreme Court held that there was a requirement of an explicit quid pro quo in official extortion cases involving campaign contributions. Then, in Evans v. United States, ${ }^{42}$ the Court held that (1) there's no requirement of inducement for official extortion; (2) official extortion doesn't require coercion; (3) bribery isn't a defense to extortion; (4) official extortion isn't limited to false pretenses; and (5) the Government "need only show that a public official has obtained a payment to which he was not entitled, knowing that the payment was made in return for official acts. ${ }^{\text {43 }}$

\section{A. McCormick v. United States}

Robert L. McCormick was a West Virginia legislator. He turned the shortage of doctors in West Virginia to his own benefit, making himself the legislative champion of graduates of foreign medical schools who wanted to practice medicine even after repeatedly failing the state licensing exams. In 1984, McCormick sponsored legislation that gave a one-year extension to a program that allowed the foreign doctors to practice while they were trying to pass. ${ }^{44}$ In May of that year, during McCormick's campaign for re-election, he had an "unfriendly" conversation with the lobbyist for the foreign doctors, saying that "he had not heard anything from the foreign doctors. ${ }^{45}$ Shortly thereafter the lobbyist produced an envelope containing $\$ 900$ in cash, and gave McCormick another $\$ 2000$ later that day. ${ }^{46}$ Other large cash payments were made during the

41111 S. Ct. 1807, 1817 (1991).

42112 S. Ct. 1881 (1992).

${ }^{43} \mathrm{Id}$. at 1889 (citation omitted).

${ }^{44}$ McCormick, $111 \mathrm{~S}$. Ct. at 1809-10.

${ }^{45} \mathrm{Id}$. at 1810 .

${ }^{46} \mathrm{Id}$. The maximum donation from any one person allowed under state law was fifty dollars. Id. at 1810 n.1; see also W. VA. CoDE § 3-8-5d (1990). 
campaign. In 1985, after re-election, McCormick sponsored legislation that permitted experienced doctors to be permanently licensed without passing the state licensing exams. The foreign doctors then made another cash payoff, long after the campaign was over. None of these payments were reported by McCormick or by the doctors' organization as campaign contributions, nor did McCormick report them on his personal tax returns. ${ }^{47}$

McCormick was convicted of extortion and income tax evasion. His conviction was affirmed by the Fourth Circuit Court of Appeals, ${ }^{48}$ but reversed in a 6-3 decision by the Supreme Court for which Justice White wrote the majority opinion. ${ }^{49}$ Justice Scalia wrote a concurrence that didn't discuss the issues raised by the case; rather, he discussed some of the other disputed issues in Hobbs Act jurisprudence that he thought the Court should take up in the future. ${ }^{50}$ Justice Stevens wrote a vigorous dissent. ${ }^{51}$

\section{Justice White's Majority Opinion in McCormick}

As to McCormick's explicit quid pro quo requirement where campaign contributions are involved, Justice White's argument is neither textual nor historical. Rather, it's a pragmatic and logical argument:

Serving constituents and supporting legislation that will benefit the district and individuals and groups therein is the everyday business of a legislator. It is also true that campaigns must be run and financed. Money is constantly being solicited on behalf of candidates, who run on platforms and who claim support on the basis of their views and what they intend to do or have done. Whatever ethical considerations and appearances may indicate, to hold that legislators commit the federal crime of extortion when they act for the benefit of constituents or support legislation furthering the interests of some of their constituents, shortly before or after campaign contributions are solicited and received from those beneficiaries, is an unrealistic assessment of what Congress could have meant by making it a crime to obtain property from another, with his consent, "under color of official right." To hold otherwise would open to prosecution not only

17 See McCormick, 111 S. Ct. at 1810.

18 McCormick v. United States, 896 F.2d 61 (4th Cir. 1990).

${ }^{49}$ McCormick, 111 S. Ct. at 1809-18.

50 See id. at 1818-20.

51 I won't comment on Justice Stevens's opinions at this point; I prefer to examine his views in the context of his majority opinion in Evans. See infra part III.B. 
conduct that has long been thought to be well within the law but also conduct that in a very real sense is unavoidable so long as election campaigns are financed by private contributions or expenditures, as they have been from the beginning of the Nation. It would require statutory language more explicit than the Hobbs Act contains to justify a contrary conclusion. ${ }^{52}$

Justice White concludes:

This is not to say that it is impossible for an elected official to commit extortion in the course of financing an election campaign. Political contributions are of course vulnerable if induced by the use of force, violence, or fear. The receipt of such contributions is also vulnerable under the Act as having been taken under color of official right, but only if the payments are made in return for an explicit promise or undertaking by the official to perform or not to perform an official act. In such situations the official asserts that his official conduct will be controlled by the terms of the promise or undertaking. This is the receipt of money by an elected official under color of official right within the meaning of the Hobbs Act. ${ }^{53}$

It appears that Justice White was concerned about either the unjust conviction of public officials for innocent campaign contributions or the chilling effect on campaign financing. He doesn't give any examples of the pre-existing law being too vigorously applied. Indeed, I can't think of a single case in which a conviction for extortion has withstood challenge when the official acted properly and the court applied the usual common law rule requiring that the official taking be wrongful or corrupt. Certainly, even Congress can't claim that the pre-existing law chilled too many large contributions. If we ask whether we have too little influence peddling in the context of campaign finances, too much influence peddling, or an optimal amount, I think everyone thinks that we have too much. So over-deterrence isn't a problem. ${ }^{54}$

What is obviously motivating Justice White is overbreadth concerns. He is worried that large campaign contributions are seldom without hope of some help. He, in effect, argues:

1. Either we have an explicit quid pro quo requirement or routine campaign contributions would fall within the coverage of the Hobbs Act.

${ }^{52}$ McCormick, 111 S. Ct. at 1816.

${ }^{33}$ Id.

54 Perhaps corruption has been selectively prosecuted and exposed. 
2. Congress couldn't have intended to cover routine campaign contributions with the Hobbs Act.

3. Therefore, if we follow Congress's probable wishes, we must have an explicit quid pro quo requirement.

The most obvious problem is with the first premise: Justice White sets up a false dichotomy. Although an explicit quid pro quo requirement will make it harder to convict, it neither solves nor supplants the inquiry necessary under the pre-existing law. Indeed, Justice White seems not to have tried to ascertain the pre-existing law. Is this new test really better than the rule that had served so well for centuries-that the payment be "corrupt" or "wrongful"?

Let's look at two situations, both involving corrupt takings without an explicit quid pro quo:

(1) An elected judge approaches a lawyer in a major case pending before the judge and says, "I haven't heard from you yet. Would you donate $\$ 100,000$ to my re-election fund?" Result: not official extortion under Justice White's test.

(2) An elected legislator approaches a businessman and says, "If you pay me $\$ 100,000$ for my campaign, I can't promise you how I'll vote on the many pieces of legislation affecting your companythat would be illegal. But if you contribute, I predict that I will vote your way." Result: not official extortion under Justice White's test.

Although both of these situations would have been Hobbs Act extortion under color of official right before $M c$ Cormick, were one to judge only from Justice White's odd opinion in McCormick, they wouldn't be now. Quid pro quos may or may not be implied in these situations, but they certainly aren't explicit. Neither explicitly promises any specific action. ${ }^{55}$

2. Justice Scalia's Concurrence in McCormick: Extortion: A False-Pretenses Offense?

Justice Scalia's concurrence in McCormick is unusual because of its silence on the issues actually decided in that case. Instead, Justice Scalia asks whether courts have been wrong all these years in interpreting extortion "under color of official right" as meaning

55 Other federal crimes besides official extortion, including perhaps extortion by fear, may or may not have been committed. 
extortion paid on account of one's office. ${ }^{56}$ He suggests that perhaps it means paid under a false claim of official right. ${ }^{57}$ He doesn't purport to decide the issue, only to raise it. And he cites authorities on both sides. ${ }^{58}$ Yet it was clear which way he was leaning before having a chance to study the issue-toward making official extortion a false-pretenses offense. This novel suggestion forms the basis of Justice Thomas's opinion in Evans, which Justice Scalia joined. ${ }^{59}$

Justice Scalia's attempt to turn extortion into a false-pretenses offense is a strange one, coming as it does so soon on the heels of academic attempts to restrict official extortion to a coercion offense. ${ }^{60}$ Indeed, the defendants' brief in Evans argues that official extortion should be limited to coercion, ${ }^{61}$ though that restriction had consistently failed in the courts of appeals.

\section{B. Evans v. United States}

In 1992 in Evans v. United States, ${ }^{62}$ the Supreme Court settled most of the open questions left by McCormick. Writing for the majority in Evans, Justice Stevens (who had dissented in McCormick) found no inducement requirement and a wide overlap between bribery and extortion. ${ }^{63}$ Justice Thomas filed a long, angry dissent (joined by Chief Justice Rehnquist and Justice Scalia) arguing for a robust inducement requirement and for a pretense of entitlement as the method of taking. ${ }^{64}$ Justice O'Connor wrote a brief concurrence, joining Justice Stevens in his rejection of an inducement

${ }^{56}$ McCormick, 111 S. Ct. at 1819.

${ }^{57}$ See id.

58 See id. at 1819-20.

59 Evans v. United States, 112 S. Ct. 1881, 1894 (1992) (Thomas, J., dissenting).

${ }^{60}$ See Andrew T. Baxter, Federal Discretion in the Prosecution of Local Political Cormution, 10 PEPP. L. REV. 321 (1983); Thomas H. Henderson, Jr., The Expanding Role of Federal Prosecutors in Combating State and Local Political Cormution, 8 CUMB. L. REV. 385 (1977); Ruff, supra note 19, at 1171; Dibble, supra note 12, at 387; Fleissner, supra note 12, at 1066; Joseph M. Harary, Note, Misapplication of the Hobbs Act to Bribery, 85 ColuM. L. REV. 1340 (1985); Laurel G. Sandler, Note, Extartion "Under Color of Official Right": Federal Prosecution of Official Corruption Under the Hobbs Act, 5 LOY. U. CHI. L.J. 513 (1974); Herbert M. Suskin, Note, Federal Prosecution of Local Political Comption: A New Approach, 29 U. MIAMI L. REV. 390 (1975); Note, United States v. Mazzei: Hobbs Act Extortion Under Color of Official Right, 62 VA. L. REV. 439 (1976).

61 See Evans, 112 S. Ct. at 1889 (citing Brief for Petitioner at 22).

62 See 112 S. Ct. 1881 (1992).

63 See id. at 1888.

64 See id. at 1894-1904 (Thomas, J., dissenting). 
requirement, but declining to consider the novel Thomas-Scalia false-pretenses argument which, she noted, hadn't been raised by the parties. ${ }^{65}$ Justice Kennedy wrote a concurrence rejecting the false-pretenses argument, but finding an inducement requirement that can be easily met by a quid pro quo. ${ }^{66}$

The New York Times implied that acrimony on the Court delayed the Evans decision. ${ }^{67}$ Later, while criticizing Justice Thomas's first year on the Supreme Court, the Times cited his dissent in Evans as evidence that "Justice Thomas has failed the test of judiciousness. ${ }^{\text {68 }}$ To my mind, the acrimony sharpened the arguments of all sides so that it's now possible to see both what's good and what's bad about them.

John $\mathrm{H}$. Evans was an elected Commissioner of DeKalb County, Georgia, who was caught accepting payoffs in a government sting operation. A special agent with the FBI, Cormany, posed as a real estate developer seeking a "leg up" on other developers in DeKalb County in obtaining rezoning approval for high-density housing. ${ }^{69}$ Through an intermediary, Cormany arranged a first meeting with Evans, leading to a series of meetings and telephone conversations between Evans and Cormany, culminating in Evans discussing his campaign financing with Cormany. ${ }^{70}$ Although demonstrating to Cormany that he needed $\$ 7885$, Evans assured Cormany that regardless of how many thousands of dollars the agent donated, Evans would do what he promised he would: "If you gave me six, I'll do exactly what I said I was gonna do for you. If you gave me one, I'll do exactly what I said I was gonna do for you." ${ }^{\text {71 }}$ Evans

${ }^{65}$ See id. at 1891 (O'Connor, J., concurring).

${ }^{66}$ See id. at 1891-94 (Kennedy, J., concurring).

67 See Linda Greenhouse, Court Upholds Widened Use of U.S. Extortion Law, N.Y. TIMES, May 27, 1992, at Al7 ("[T]he case apparently provoked an intense debate within the Court in the nearly six months since it was argued.").

${ }^{68}$ See Justice Thomas, the Freshman, N.Y. Times, July 5, 1992, § 4, at 10.

New justices are as free as any others to be cranky, stubborn, loud or vigorous. That's not what's troublesome looking back over Justice Thomas's record. The problem is that his arguments read more like boilerplate attacks on political opponents than lawyerly debates with colleagues on the same bench.

In a quarrel over the scope of the Federal extortion law, he accused his colleagues not merely of rejecting better interpretations but of making up their own version of the law.

Id.

69 United States v. Evans, 910 F.2d 790, 792 (11th Cir. 1990).

${ }^{70} \mathrm{Id}$. at 792-94.

${ }^{71} \mathrm{Id}$. at 794. 
also requested that $\$ 1000$ of the donation be by check and the rest in cash. ${ }^{72}$ Evans reported the $\$ 1000$ check as a campaign contribution, but "locked the $\$ 7000$ in cash in a drawer in a file cabinet in his campaign office" and failed to report it in either his campaign reports or his tax return. ${ }^{73}$ He was convicted of extortion under color of official right and income tax evasion, and his conviction was affirmed by the Eleventh Circuit Court of Appeals ${ }^{74}$ and by the United States Supreme Court. ${ }^{75}$

\section{Inducement}

The issue on which certiorari was granted was whether the official has to have induced the payment, and if so, what constitutes inducement. ${ }^{76}$ The inducement question is a complex one because the inducement requirement intersects with other issues, such as the parsing of the language of the Hobbs Act and possible requirements that the official make a demand, use coercion beyond that implicit in his office, or initiate negotiations.

The place to start is with the Hobbs Act. It provides: “(2) The term 'extortion' means the obtaining of property from another, with his consent, induced by wrongful use of actual or threatened force, violence, or fear, or under color of official right." ${ }^{n 7}$ The first question is whether the word "induced" applies only to coercive extortion or whether it applies to both coercive and official extortion. Justice Stevens argued:

First, we think the word "induced" is a part of the definition of the offense by the private individual, but not the offense by the public official. In the case of the private individual, the victim's consent must be "induced by wrongful use of actual or threatened force, violence or fear." In the case of the public official, however, there is no such requirement. The statute merely requires of the public official that he obtain "property from another, with his consent, ... under color of official right." The use of the word "or" before "under color of official right" supports this reading.

Second, even if the statute were parsed so that the word "induced" applied to the public officeholder, we do not believe the

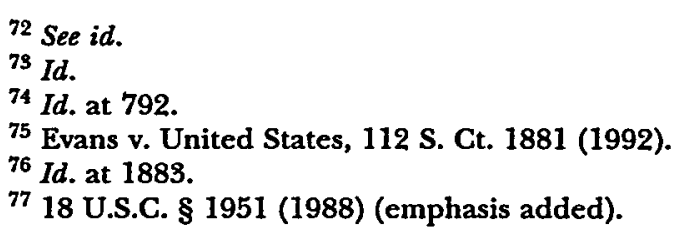


word "induced" necessarily indicates that the transaction must be initiated by the recipient of the bribe. Many of the cases applying the majority rule have concluded that the wrongful acceptance of a bribe establishes all the inducement that the statute requires. They conclude that the coercive element is provided by the public office itself. And even the two courts that have adopted an inducement requirement for extortion under color of official right do not require proof that the inducement took the form of a threat or demand. ${ }^{78}$

Thus, under the Court's majority opinion in Evans, official extortion has no inducement requirement.

Justices Kennedy and Thomas disagree with Justice Stevens's first argument, arguing instead that "induced" applies to both coercive and official extortion. ${ }^{79}$ As much as I disagree with the rest of Justice Thomas's opinion, on this limited point I believe he's correct. Reading "induced" as applying to official extortion is the most natural way to read the statute.

Further, this statutory language was borrowed from the Field Code of 1865, which was enacted as the New York Penal Code in $1881 .^{80}$ In the original Field Code, the official commentary stated: "In extortion there is again a taking. Now it is with the consent of the party injured; but this is a consent induced by threats, or under color of some official right." ${ }^{81}$ Although it's possible to again read "induced" as not applying to "under color of . . . official right," I find such a disjunctive reading more difficult for the Field Code commentary. One can read the Hobbs Act as saying "obtaining . . . under color of official right," but in the comments to the Field Code, the word "obtaining" doesn't appear, and thus can't be used as a crutch to support a disjunctive reading.

The real question should be how much independent content should be given to the word "induced," other than as introducing the situation that induces the payment, "under color of official right." On this I am in basic agreement with the Evans majority. Justice Thomas, on the other hand, seems to jump from his parsing of the statutory language to an argument that the official must have very actively defrauded the payor into making an unwarranted payment.

${ }^{78}$ Evans, 112 S. Ct. at 1888 (footnotes omitted).

79 See id. at 1892 (Kennedy, J., concurring); id. at 1897 (Thomas, J., dissenting).

${ }^{80}$ See supra note 1 .

${ }^{81}$ FIELD CODE, supra note 1 , at $\$ 584$, commentary at 210 (1865). 
Justice Stevens's fallback position ${ }^{82}$ (which is close to Justice Kennedy's view) ${ }^{83}$ makes more sense to me. As most Courts of Appeals that addressed the issue have held, the wrongful acceptance of a bribe is enough to meet any inducement requirement. ${ }^{84}$ This is what $I$ call the situational inducement approach. As long as the official receives the wrongful payoff knowing that it's paid on account of his office (or under Evans, in return for official services), official extortion has been committed. This approach is most consistent with the language and common law origins of the Hobbs Act.

The idea that the official himself must do the inducing has been advanced by some courts and several commentators, but the statutory language says nothing of the kind. It states the situation under which extortion must be induced, under color of official right. It says nothing about an inducer. Unlike some blackmail and private citizen extortion statutes that punish the threatener, ${ }^{85}$ the Hobbs Act quite pointedly punishes the person who obtains the property, not the person or situation that induces the transfer. The statute wisely avoids getting into discussions about when the acts of others are chargeable to the official. As long as the situational requirement is met, any inducement requirement should automatically be satisfied. This is consistent with the historical approach to extortion, an approach unconcerned with the precise method of wrongful taking-bribery, coercion, or false pretenses. Thus, while I agree with Justice Thomas that the word "induced" probably applies to official extortion, I agree with Justice Stevens and the majority that the word "induced" adds nothing to the other elements required for extortion. This isn't reading the word

82 See Evans, 112 S. Ct. at 1889.

${ }^{83}$ See id. at 1892 (Kennedy, J., concurring).

${ }^{84}$ See United States v. Holzer, 816 F.2d 304, 311 (7th Cir. 1987) ("Extortion 'under color of official right' equals the knowing receipt of bribes . ..."); United States v. Butler, 618 F.2d 411, 418 (6th Cir.) ("[A] showing that the motivation for the payment focuses on the recipient's office, regardless of who induces the payments, is sufficient to convict under the Hobbs Act."), cert. denied, 447 U.S. 927 (1980); United States v. Braasch, 505 F.2d 139, 151 (7th Cir. 1974) ("So long as the motivation for the payment focuses on the recipient's office, the conduct falls within the ambit of [the Hobbs Act]."), cert. denied, 421 U.S. 910 (1975); see also Dibble, supra note 12, at 395; Fleissner, supra note 12, at 1073-74.

${ }^{85}$ See, e.g., FlA. STAT. ch. 836.05 (1991) ("Whoever . . . maliciously threatens to accuse another of any crime . . . with intent to extort money ... shall be guilty of a felony .....”). 
"induced" out of the statute; rather, it's reading it together with the words "under color of official right."

I'm comfortable with the Court's holding that there is no inducement requirement because that's certainly a simpler and easier rule to apply than a rule that inducement is met by the situation of the receipt of the payoff-under color of official right.

\section{Color of Official Right}

Just about everyone (including both Justices Stevens and Thomas) agrees that the Hobbs Act language "color of official right" is equivalent to the old common law terms "color of office" or "colore officii." ${ }^{86}$ In Evans, Justice Stevens adopts my theory of the history of extortion ${ }^{87}$-that extortion under color of office embraced takings by coercion, false pretenses, and bribery. ${ }^{88}$ Thus bribe-taking is extortion when it meets the other requirements of the statute.

At the time I wrote my history, there were a large number of student notes, and even a few commentaries by academics, arguing chiefly that extortion at English common law required coercion. ${ }^{89}$ They were so inadequately researched that between them they didn't cite even one early English extortion case in support of their position. ${ }^{90}$ In contrast, $I$ have found scores of English and American cases and statutes where the method of taking was bribery or false pretenses, ${ }^{91}$ thus exploding the myth that extortion was limited to coercion.

Most of these authors also argued that under New York law, which was a model for the Hobbs Act, official extortion and bribery were mutually exclusive. I discovered that the cases they cited in support weren't even official extortion cases, but rather were coercive extortion cases. ${ }^{92}$ Further, I found only one New York

${ }^{86}$ See Evans, 112 S. Ct. at 1885 \& nn. 4-5; id. at 1895 \& n.I (Thomas, J., dissenting); see also Lindgren, supra note 4, at $819-20 \&$ n.24.

${ }^{87}$ See Evans, 112 S. Ct. at 1885.

${ }^{88}$ See generally Lindgren, supra note 4.

${ }^{89}$ See sources cited supra note 60.

${ }^{90}$ Noonan, however, cites one English statutory extortion case-the impeachment proceedings of Warren Hastings. See NoONAN, supra note 6, at 398 . Unfortunately, those proceedings charged Hastings with extortion for receiving a bribe, so Noonan doesn't offer the case as support for his position, but rather as an incorrect example. See id.

91 See Lindgren, supra note 4, at 851-72, 885-86, 896-902.

${ }^{92}$ See id. at $902-03$. 
case directly on point, People v. Hansen..$^{93}$ In that case, convictions for bribery and extortion under color of official right were sustained on the same facts, even though the defendant unsuccessfully argued on appeal that these crimes were mutually exclusive. ${ }^{94}$ Moreover, I pointed out that by New York statute, the method of taking for official extortion was the same as for bribery-asking, receiving, or agreeing to receive a payment. ${ }^{95}$

I also explored the origins of the Hobbs Act language in Hawkins's and Coke's early definitions of common law extortion, and in the nineteenth century Field Code. ${ }^{96}$ In the late nineteenth century, after the "color of official right" language was drafted, some American courts became confused over the original scope of common law extortion. Thus, in the early twentieth century, the cases were a mess. ${ }^{97}$ Some courts still got it more or less right; some even upheld convictions for extortion and bribery on the same facts. ${ }^{98}$ But other courts suggested that extortion was coercive while bribery was voluntary or offered other odd ways to drive the two crimes apart, ${ }^{99}$ such as issuing dicta used by Justices Scalia and Thomas to support their false-pretenses view. Without trying to sort out which was the larger group of cases, I pointed out (1) that the courts taking novel approaches were not aware that they had

93150 N.E. 542 (N.Y. 1925), affg 207 N.Y.S. 894 (1924) (affirming a judgment "rendered upon a verdict convicting the defendant of the crimes of extortion, bribery and taking unlawful fees"). For a discussion of the facts of this case, see Lindgren, supra note 4, at 901 .

94 Hansen, 150 N.E. at 542.

${ }^{95}$ See Lindgren, supra note 4, at 897-900 (comparing N.Y. PENAL LAW \$ 557 (1881), under which the method of taking for extortion is "asks, or receives, or agrees to receive" with N.Y. PENAL LAW $\$ \S 45,67, \& 72$ (1881), under which the method of taking for bribery is also defined as "asks, receives, or agrees to receive").

96 See Lindgren, supra note 4 , at 862-65, 892-96.

${ }^{97}$ See id. at 886-87 (noting that "cases began to misstate the traditional scope of common law extortion").

98 See Martin v. United States, 278 F. 913 (2d Cir. 1922) (involving visa officer convicted of both bribery and official extortion for taking $\$ 30$ "grease" payment to speed up processing); State v. Vallee, 12 A.2d 421 (Me. 1940) (holding shakedown of public janitor by county commissioner to be both extortion by fear and bribery); People v. Hansen, 150 N.E. 542 (N.Y. 1925) (per curiam), affg 207 N.Y.S. 894 (1924) (upholding convictions for both bribery and extortion under color of official right on the same facts, despite defendant's argument that the two crimes were mutually exclusive); Commonwealth v. Brown, $23 \mathrm{~Pa}$. Super. 470 (1903) (holding that the object offenses of a conspiracy to take payoffs to appoint teachers are both extortion and bribery).

${ }^{99}$ See Daniels v. United States, 17 F.2d 339, 342 (9th Cir.), cert. denied, 274 U.S. 744 (1927); United States v. Harned, 43 F. 376, 377 (D. Wash. 1890); State v. Pritchard, 12 S.E. 50, 52 (N.C. 1890). 
misunderstood common law extortion, and (2) that the coercion side channel was eventually rejected by the United States Courts of Appeal after 1972. ${ }^{100}$

Interestingly, the attack has shifted since my article was published. The previous two main supports for the position opposing mine-English common law and New York law-have been largely jettisoned. Now the attack is centered on the only set of authorities that I didn't analyze in depth-American cases of the late nineteenth and early twentieth century outside of New York. ${ }^{101}$

While I think that these cases are relevant, I don't agree that they are the most relevant group of authorities. First, as Justice Stevens argues, we should interpret "terms of art" according to "the legal tradition and meaning of centuries of practice. 102 Justice Stevens also argues, quoting Justice Frankfurter, that "if a word is obviously transplanted from another legal source, whether the common law or other legislation, it brings the old soil with it. ${ }^{n 103}$ The Hobbs Act's roots run through the Field Code to Wharton, and ultimately to Hawkins. ${ }^{104}$ Thus, its language is common law language and should be so interpreted. Most of the twentieth century cases, in contrast, are cases of statutory extortion.

Second, I find it hard to rely too heavily on the case law when it's so confused and disparate. If it were clear and pointed in one direction, I would afford it great weight. But it's a swamp. Anyone who suggests that the late nineteenth and early twentieth century cases are clear is either less than candid or hasn't done enough research. ${ }^{105}$

${ }^{100}$ See Lindgren, supra note 4, at 817-18 \& nn.15-17.

101 See infra note 105.

${ }^{102}$ Evans v. United States, 112 S. Ct. 1881,1885 (1992) (quoting Morissette v. United States, 342 U.S. 246, 263 (1952)).

${ }^{103}$ Id. at 1885 n.3 (quoting Felix Frankfurter, Some Reflections on the Reading of Statutes, 47 COLUM. L. REV. 527, 537 (1947)).

104 See Lindgren, supra note 4 , at 887, 892-96.

105 While this article was in draft, an article was published that attacked my position. See Dan K. Webb et al., Limiting Public Corruption Prosecutions Under the Hobbs Act: Will United States v. Evans be the Next McNally?, 67 CHI.-KENT L. REV. 29 (1991). Contrary both to my contention that extortion included bribery and to Justice Thomas's contention that extortion was limited to a pretense of entitlement, the Webb article contends that extortion was limited to "coercion, duress or inducement." Id. at 47. Of course, these are far from equivalent claims. If only inducement is required, the agreement to receive it might constitute the inducement. I have always thought that the Hobbs Act required inducement because of the statute's particular language, but that knowing receipt is all that's needed for inducement. See supra part III.B.1. Most federal courts before Evans also agreed that coercion wasn't required and that any inducement was easily met by knowing receipt. 


\section{Third, I grant much less weight to opinions that attempt to follow the traditional meaning of extortion, but unwittingly make}

To the extent that the Webb article argues that coercion is required, it picks up the main line of academic attack on the Hobbs Act that had prevailed before I published my 1988 history. I frankly thought that this large, mostly reciprocal-citing academic literature had been laid to rest, but I see that it's not quite dead yet. The authors are lawyers at Winston \& Strawn, at least two of whom have defended accused or convicted corrupt officials. Indeed, their article reads as if it were a recycled brief, though because it lacks the usual disclaimer of past paid representation to take the positions expressed, it may not be.

In my 1988 article, see supra note 4, I showed that the two main pillars of the coercion thesis-the English common law and New York law-didn't support their edifice, but instead strongly supported my contrary conclusion, that extortion wasn't limited to coercion. See id. Interestingly, in the Webb article, the English common law is rejected as irrelevant, and their discussion of New York law consciously ignores the only case on point, People v. Hansen, 150 N.E. 542 (N.Y. 1925). Besides their misreliance on New York law, the defense lawyer-authors otherwise rely on the only set of authorities that I didn't systematically examine (or claim to examine)-the case law in jurisdictions other than New York before the Hobbs Act was passed in 1946.

In 1988, I argued that in the late nineteenth century, the law of extortion split into two channels, one getting it more or less correctly and one getting it wrong. See Lindgren, supra note 4 , at 886 . Contrary to the implications of the defense lawyers, I made no claims about which channel was larger. Rather, I claimed that the "extortion as coercion" view was a side channel in the sense that it was inconsistent with both the earlier history and the later understanding in the modern federal courts. The defense lawyers argue, on the other hand, that there was essentially only one view at the time-theirs.

This puts our descriptions squarely at odds. They claim that there was only one channel; I claim that there were two. They claim that the law was clear; I claim that it was a mess. That's why I carefully traced the origins of the Hobbs Act language in the New York Field Code and the English common law treatises before the law split into two channels. Because I always claimed that there were some cases expressing their view of the law and they claim that their view was essentially the only view, I can easily establish that my view of multiple approaches is the correct characterization. All I have to do is show some cases where bribery behavior was punished as extortion. I can do better than that. In four cases-Martin, Vallee, Hansen, and Browndefendants were convicted of both extortion and bribery on the same facts. See supra notes 10, 93-94 \& 98 and accompanying text. For the more common cases where bribery behavior was punished as extortion, see Lindgren, supra note 4, at 852-62, 904-05; David Burgess, The Meaning of "Under Color of Office" 28-30 (Mar. 26, 1993) (unpublished manuscript on file with the author).

The full history of the case law of the various jurisdictions before the Hobbs Act was passed is yet to be written. The Webb article is helpful because it collects most of the cases on one side of the debate, but its characterizations are totally unpersuasive, particularly on New York law and federal law, because they ignore the contrary evidence. This style of brief-writing is always risky before a scholarly court of appeals, but it's deadly in the law reviews where someone may have the time to look at the larger history. And it's too easy to refute. Any substantial contrary evidence proves them wrong. Moreover, an analysis of these confusing cases may be imminent: David Burgess, a student of mine, is undertaking a review of the meaning of "color of office” preceding the Hobbs Act's enactment in 1946. 
new law, than I grant to opinions by judges who know what they're doing and follow the traditional meaning of extortion. I thus give more weight to cases that are in the tradition of centuries-that is, cases that are consistent with both earlier and later cases.

\section{Justice Thomas's Theory That Color of Office Means False Pretenses}

After citing Hawkins's and Blackstone's definitions of extortionwhich make no mention of the method of taking besides that it be by color of office or official right-Justice Thomas argues:

These definitions pose, but do not answer, the critical question: what does it mean for an official to take money "by colour of his office"? The Court fails to address this question, simply assuming that common-law extortion encompassed any taking by a public official of something of value that he was not "due."

The "under color of office" element of extortion, however, had a definite and well-established meaning at common law. At common law it was essential that the money or property be obtained under color of office, that is, under the pretense that the officer was entitled thereto by virtue of his office. ${ }^{106}$

Justice Thomas's attack on my article is both direct and indirect. First, he criticizes Justice Stevens's heavy reliance on my work:

The Court's historical analysis rests upon a theory set forth in one law review article. See ante, at 1884-85, and nn. 4-6 (citing Lindgren, The Elusive Distinction Between Bribery and Extortion: From the Common Law to the Hobbs Act, 35 UCLA L. Rev. 815 (1988)). Focusing on early English cases, the article argues that common-law extortion encompassed a wide range of official takings, whether by coercion, false pretenses, or bribery. Whatever the merits of that argument as a description of early English common law, it is beside the point here-the critical inquiry for our purposes is the American understanding of the crime at the time the Hobbs Act was passed in 1946. ${ }^{107}$

In a footnote, he goes on to express skepticism about my account of common law extortion:

Those merits are far from clear. Most commentators maintain that extortion and bribery were distinct crimes at early English

${ }^{106}$ Evans, 112 S. Ct. at 1895 (Thomas, J., dissenting) (citations omitted).

${ }^{107}$ Id. at 1895-96 (Thomas, J., dissenting). 
common law. See, e.g., J. Noonan, Bribes 398, 585-587 (1984); Ruff, Federal Prosecution of Local Corruption: A Case Study in the Making of Law Enforcement Policy, 65 Geo. L.J. 1171, 11791180 (1977). While - as I explain below-Professor Lindgren may well be correct that common-law extortion did not contain an "inducement" element, in my view he does not adequately account for the crime's "by color of office" element. This latter element has existed since long before the Founding of the Republic, and cannot simply be ignored. As Chief Justice Montague explained over four centuries ago, colore officii sui ("by color of his office") "signifies an Act badly done under the Countenance of an Office, and it bears a dissembling Visage of Duty, and is properly called Extortion." Dive v. Maningham, 1 Plowd. 60, 68, 75 Eng. Rep. 96 (C.B. 1550) (emphasis added). See also $3 \mathrm{E}$. Coke, Institutes *542 (describing extortion as "more odious than robbery; for robbery is apparent, and hath the face of a crime, but extortion puts on the visure of virtue") (emphasis added). ${ }^{108}$

Justice Thomas contends that color of office is what distinguishes official extortion from bribery. According to Justice Thomas, color of office means a pretense that the money was owing. $\mathrm{He}$ argues:

Regardless of whether extortion contains an "inducement" requirement, bribery and extortion are different crimes. An official who solicits or takes a bribe does not do so "under color of office"; i.e., under any pretense of official entitlement. ${ }^{109}$

This would turn extortion into a false-pretenses offense.

Yet there are big problems with Justice Thomas's argument. The first problem is noted by Justice Stevens and echoed by Justice Kennedy. Justice Stevens argues:

The dissent's theory notwithstanding, not one of the cases it cites holds that the public official is innocent unless he has deceived the payor by representing that the payment was proper. Indeed, none makes any reference to the state of mind of the payor, and none states that a "false pretense" is an element of the offense. Instead, those cases merely support the proposition that the services for which the fee is paid must be official and that the official must not be entitled to the fee that he collected-both elements of the offense that are clearly satisfied in this case. The complete absence of support for the dissent's thesis presumably explains why it was not advanced by petitioner in the District

${ }^{108}$ Id. at $1896 \mathrm{n} .2$ (Thomas, J., dissenting).

${ }^{109}$ Id. at 1897 (Thomas, J., dissenting). 
Court or the Court of Appeals, is not recognized by any Court of Appeals, and is not advanced in any scholarly commentary. ${ }^{110}$

If you read the cases that Justice Thomas cites for his view, his argument looks even weaker: none offer direct support for his position. A few have dicta pointing in his direction ${ }^{111}$ or are based on special statutes that explicitly required something beyond the common law crime. ${ }^{112}$ But most of Justice Thomas's cases offer no support of any kind, merely showing that false pretenses is a proper class of extortion case, not that false pretenses are necessary. Indeed, two of the cases he cites, Dean v. State ${ }^{113}$ and Hanley v. State, ${ }^{114}$ held more or less the opposite. In Dean, the defendant challenged the indictment, claiming that it was "defective, because it is not alleged whether the defendant was executing, or pretending to execute, some legal ... paper under color of his office. ${ }^{115}$ The court rejected the defendant's claim, affirming the conviction, and stating that extortion didn't require a pretense of legal process. ${ }^{116}$ In addition, the court noted that the defendant "may be guilty if he extorts such money upon promise not to execute. ${ }^{117}$ If a person commits extortion by taking money for promising not to execute legal process (when obviously no fee is owing), how can it be said that the money is taken under a pretense of entitlement, accepted in right of office, or obtained from victims

${ }^{110}$ Evans, 112 S. Ct. at 1890 (citation omitted). Justice Kennedy argues:

While the dissent may well be correct that prior to the enactment of the Hobbs Act a large number of the reported official extortion cases in the United States happened to involve false pretenses, those cases do not so much as hint that a false pretense of right was ever considered as an essential element of the offense. Furthermore, as the Court demonstrates, during the same period other American courts affirmed convictions of public officials for extortion based upon corrupt receipt of payment absent any claim of right.

Id. at 1893-94 (Kennedy, J., concurring) (citations omitted). I think that Justice Kennedy goes a bit too far. There are certainly hints in some of the cases that false pretenses might be an element of the offense.

III See, e.g., Collier v. State, 55 Ala. 125, 127-28 (1876).

112 See, e.g., Commonwealth v. Bagley, 24 Mass. (7 Pick.) 279, 279 (1828) (involving an unusual Massachusetts extortion statute that required that a defendant "demand and receive," rather than the more typical "demand or receive").

11371 S.E. 597 (Ga. Ct. App. 1911).

114104 N.W. 57 (Wis. 1905).

115 Dean, 71 S.E. at 598.

116 See id. at 598 .

117 Id. at 598-99. 
yielding to official authority? Payoffs to officials for not doing their jobs are bribes and, as Dean holds, such payoffs are extortion.

Another of Justice Thomas's cited cases, Hanley $v$. State, ${ }^{118}$ rejects the defendants' claim that extortion is limited to a demand for a fee to which the defendants were not entitled. The Wisconsin Supreme Court distinguished a narrower case of statutory extortion ${ }^{119}$ from the broader common law extortion offense that had been codified in Hanley. Once again, Justice Thomas's approach to common law extortion was explicitly rejected in a case he cites for support.

What is perhaps more devastating to Justice Thomas's view is that both extortion and bribery were and are color of office offenses. Thus, color of office can't distinguish bribery from extortion and it doesn't mean anything that wouldn't apply equally to bribery and extortion. Color of office can't require false pretenses, because then both extortion and bribery would have to be false-pretense offenses. To illustrate this problem with Justice Thomas's argument, I will start with one of the authorities he cites above-Coke's Institutes.

Note Coke's definition of bribery:

Bribery is a great misprision when any man in Judicial place takes any Fee or Pension, Robe, or Livery, Gift, Reward or Brocage of any person, that hath to do before him any way, for doing his office, or by colour of his office, but of the King only, unless it be of meat and drink, and that of small value, upon divers, and grievous punishments. ${ }^{120}$

According to Coke, bribery was a color of office offense, as was extortion. ${ }^{121}$

118104 N.W. 57 (Wis. 1905).

119 See State v. Oden, 37 N.E. 731, 732 (Ind. 1894) (pointing out that common law extortion was broader than the extortion fee statute involved in the case).

120 EDWARD COKE, THIRD INSTITUTE 587 (J. Thomas ed., 1826) (emphasis added).

${ }^{121}$ See id. ("But largely extortion is taken for any oppression by extort power, or by colour or pretence of right ...."); see also id. at 584 ("Extortion, in its proper sense, is a great misprision, by wresting or unlawfully taking by any officer, by colour of his office, any money or valuable thing ... either that is not due, or more than is due, or before it be due ...."). 
Hawkins, who was the ultimate source for the official right language in the Hobbs Act, ${ }^{122}$ also defined bribery as a color of office offense:

Bribery in a strict sense is taken for a great misprision of one in a judicial place, taking any valuable thing whatsoever, except meat and drink of small value, of any one who has to do before him any way for ... doing his office, or by colour of his office, but of the king only. ${ }^{123}$

An interesting aspect of Coke's and Hawkins's definitions is that, because takings "for doing his office" are what one traditionally thinks of as extortion-type behavior, takings "by colour of office" must represent takings not to perform properly, which is the core of bribery. Thus, not only does color of office cover bribery, but it's used in bribery definitions to describe the central kind of bribery: takings to pervert official decisionmaking. Those who would read color of office as referring only to a pretense that the money was owed would be cutting out not just a large part of the law of extortion, but the very core of the crime of bribery itself. In short, an official fulfilling his duties properly without taking corrupt payments is acting by virtue of his office. An official acting improperly in his official duties acts under the color of his office. His office provides cover for his corruption; ${ }^{124}$ it gives his misdeeds the "color of official right." Like most white-collar criminals, an official taking bribes or extortion payments has a semblance or appearance of proper or right behavior, but acts corruptly. Coke explains that colour officii refers to acts in the bad part of an office, while virtute officii refers to acts in the good part of an office. ${ }^{125}$

\section{Hawkins defined extortion:}

[I] $t$ is said, That extortion in a large sense signifies any oppression under colour of right; but that in a strict sense, it signifies the taking of money by any officer, by colour of his office, either where none at all is due, or not so much is due, or where it is not yet due.

William Hawrins, 1 A Treatise of the Pleas of the Crown 316 (Thomas Leach ed., 6th ed. 1788).

${ }^{123} 1$ id. at $311-12$ (emphasis added).

124 See, e.g., Commonwealth v. Norris, 87 Pa. Super. 61, 64 (1925) (involving an officer who used official authority to receive a payoff in exchange for allowing a prisoner to go free).

125 I EDWARD CoKe, SECOND INSTITUTES 206 (1799 ed.) ("Colour officii is ever taken in malem partem, as virtute officii is taken in bonam: and therefore this implyeth a seisure unduly made against law."). 
Color of office has remained part of the definition of bribery offenses to the present day. Consider these statements from twentieth-century bribery cases:

(1) "[T] he essence of the crime [of bribery] is the fact that he agreed to do it under color of office." 126

(2) It is not essential that the official action induced by the bribe be lawful; it is sufficient that it is official in form and done under color of office, so that the offer, or receipt by an authorized officer, of a bribe to release one from arrest is criminal without regard to the legality of the arrest.

The official act influenced by the bribe need not be lawful to render one liable for bribery, but need only be official in form, and done under color of office. In other words, as long as the officer's act has actual relation to his official employment, it is immaterial that the law imposes no duty on him to act or that he has no direct authority to act. Thus it is not necessary, in order to constitute bribery, that the public official be influenced in regard to a measure which can be legally enforced. ${ }^{127}$

(3) He asked and agreed to take $\$ 500$ in money, and promised that in consideration thereof he would discharge the accused after hearing the charge against him. While "in judicial place" he agreed to take a bribe for doing an act official in character, and which was in the nature of an "official proceeding." For a certain amount of money he was to make a certain decision as coroner, and it was because he had power to make that decision that he was able to exact a bribe. All his acts were official in form, and all that he did was by color of his office. ... It is sufficient if the defendant assumed, colore officii, to perform a function belonging to his office, even if the right to perform it did not exist in the particular case. ${ }^{128}$

(4) The thrust of the malfeasance charges ... stems from the offer to accept the bribe, and not any actual acceptance of bribe money. "Public officers ... are indictable for corruption if they accept or offer to accept, under color of office, any money or other benefit calculated in any way to influence their official course ... .

${ }^{126}$ State v. Hendricks, 186 P.2d 943, 947 (Ariz. 1947) (emphasis added) (quoting 1 BURDICR, LAW OF CRIME § 291).

127 Vinyard v. United States, 835 F.2d 176, 182-83 (8th Cir.) (emphasis added) (quoting 11 C.J.S. Bribery \& 2e(3) (1938)), cert. denied, 379 U.S. 930 (1964).

128 People v. Jackson, 84 N.E. 65, 67 (N.Y. 1908) (emphasis added).

129 Wallace v. State, 211 A.2d 845, 850 (Del. 1965) (second emphasis added) 
(5) [T] he defendant used the real or supposed power of this office to obtain money for himself by a corrupt trade in violation of his public duty, and that under color of his office he exercised de facto the power needed to accomplish what he set out to do. In a situation of this kind there is present every element which renders the acceptance of a bribe abhorrent to all right thinking people. ... We do not mean to say that an officer can be convicted of bribery in respect to acts entirely unrelated to his office. But where as here he acts under color of his office we think that a sufficient relation exists. ${ }^{\text {130 }}$

(6) A bribery charge is "dependent on the evidence as to the extent, if at all, [the defendants] acted, or assumed to act, officially, or colore officii..131

(7) It is unnecessary to determine "whether an offense committed under color of office was bribery or extortion." ${ }^{\text {132 }}$

One can get a good idea of what "color of office" means from its use in these cases. It usually refers to the occasion for the payment and what the officer intends to do if paid. As Justice Montague says in the passage quoted by Justice Thomas, colore officii "signifies an act badly done under the countenance of an office. ${ }^{n 33}$ The case from which this statement is taken, Dive v. Maningham, ${ }^{134}$ nicely shows the overlap of bribery and extortion. There, for a bribe, a sheriff released a prisoner in custody on a debt. The prisoner's brother gave the sheriff a bond promising a payoff to the sheriff and agreeing to indemnify the sheriff if the King or the creditor were to sue the sheriff for letting the prisoner escape. The sheriff then sued on the bond to collect his bribe, but such bonds were by statute void in part because they were taken by "colure officii." 135 The court called such schemes "bribery" and "extortion," and gave judgment for the prisoner's brother. Montague further illustrated the meaning of color of office when he explained how a sheriff can

(quoting 2 WHARTON's CRIMINAL LAW § 1900 at 2236-97 (1932)) (describing a conviction for malfeasance for agreeing to accept a bribe).

${ }^{130}$ Commonwealth v. Avery, 18 N.E.2d 353, 354 (Mass. 1938) (emphasis added).

131 State v. Carney, 14 Ohio Op. 298, 302 (Com. Pleas Ct. 1939) (emphasis added).

132 United States v. Butler, 618 F.2d 411, 419 (6th Cir.) (emphasis added), cert. denied, 447 U.S. 927 (1980).

133 Dive v. Maningham, 75 Eng. Rep. 96, 108 (C.B. 1550) (quoted in Evans v. United States, 112 S. Ct. 1881, 1896 n.2 (1992) (Thomas, J., dissenting)).

134 Id.

${ }^{135}$ Id. at $107-08$. 
act illegally while acting officially: "he took it unduly, . . . but yet he took it as sheriff, ergo he took it colore officii sui." ${ }^{136}$

Another passage quoted by Justice Thomas defines "color of office" in part as

"the use of official authority as a pretext or cover for the commission of some corrupt or vicious act; an act evilly done, by the countenance of an office; an act unjustly done by the countenance of an office; an act wrongfully done by an officer under the pretended authority of his office. ${ }^{\text {137 }}$

The case that Justice Thomas cites as "typical case, ${ }^{n 138}$ Collier v. State, ${ }^{139}$ is an illustration of the real meaning of color of office. In Collier, a prosecutor took a fee, not for his official services as a prosecutor, but for extra services as a lawyer rendering legal advice. Although there is dictum in the opinion supporting Justice Thomas's false-pretenses view, the case concerns a statute narrower than common law extortion. Moreover, the actual holding is that if an official takes a fee for real services outside his official ones, he doesn't take the property under color of office. ${ }^{140}$ Here the case was drawing the usual extortion distinction between apparently official acts and extra services. In both the law of bribery and the law of extortion, color of office performs the same function. It limits these crimes to payoffs for official acts or acts that appear to be official acts.

Judge Noonan (who views extortion as necessarily coercive) incorrectly states in his superseded Aguon opinion, "If money was paid voluntarily, it was not obtained by the officer "by color of his office." 141 If that were true, then bribery could not be voluntary because bribery and extortion are both offenses committed "by color of office." Rather than distinguish extortion from bribery, the traditional "color of office" language links the two offenses.

${ }^{136}$ Id. at 108; see also Steven L. Winter, The Meaning of "Under Color of" Law, 91 MICH. L. REV. 325, 345 (1992) (accurately discussing Dive at length, but making no mention of the McCormick or Evans cases debating the meaning of the phrase "under color of"; article appeared while this Article was in press).

${ }^{137}$ Evans v. United States, 112 S. Ct. at 1895 n.1 (1992) (Thomas, J., dissenting) (quoting 7 Cyclopedia of Law and Procedure 401-02 (1903)).

${ }^{138}$ Id. at 1896 (Thomas, J., dissenting).

13955 Ala. 125 (1876).

140 See id. at 127.

141 United States v. Aguon, 813 F.2d 1413, 1416 (9th Cir. 1987), superseded, 851 F.2d 1158 (9th Cir. 1988) (en banc). 


\section{Noonan and Ruff}

Justice Thomas also cites Judge John Noonan's Bribes ${ }^{142}$ and Charles Ruff's Federal Prosecution of Local Corruption ${ }^{143}$ as contrary authority to my history of extortion at English common law. But neither Noonan nor Ruff wrote a history of extortion and neither cites any extortion cases to support their views that extortion was limited to coercion at English common law. Ruff appears mostly to have depended on two common law treatises and, although the treatises don't claim that extortion was coercive, he squeezes their claims into that mold. In all, Ruff has only seven sentences of text on the history of common-law extortion. None of the authorities he cites say that extortion is coercive. ${ }^{144}$

142 See NoONaN, supra note 6, cited in Evans, 112 S. Ct. at 1896 n.2 (Thomas, J., dissenting).

143 See Ruff, supra note 19, cited in Evans, 112 S. Ct. at 1896 n.2 (Thomas, J., dissenting).

144 Here is the entire text of Ruff's history of common law extortion:

Blackstone described the crime of extortion as "an abuse of public justice, which consists in an officer's unlawfully taking, by colour of his office, from any man, any money or thing of value, that is not due him, or more than is due, or before it is due." The historical roots of this offense may be traced to the Roman leges repetundarum, which, beginning in 171 B.C., prohibited magistrates and, later, other public officials from profiting by their positions. A comparable offense appeared in England as early as 1275. Chapter 26 of the Statute of Westminster I, entitled "Extortion by the King's Officers," provided in part that "no Sheriff, nor other the King's Officer, take any reward to do his Office, but shall be paid of that which they take of the King; and he that so doth, shall yield twice as much, and shall be punished at the King's Pleasure." The bulk of this statute still remains in force, although its specific references to sheriff and coroners have been recodified in other legislation.

The earliest recorded decision interpreting the extortion provision of the Statute of Westminster I arose in the context of a civil suit by Lewis Dive, sheriff of Bedford, against John Maningham in the amount of $£ 40$, representing a bond for the release pending trial of a prisoner in the sheriff's custody. In finding for the defendant, Chief Justice Mountague concluded, in part, that the plaintiff had demanded payment improperly colore officii and stated:

[For] this Word colore officii sui is always taken in malem partem, and signifies an Act badly done under the Countenance of an Office, and it bears a dissembling Visage of Duty, and is properly called Extortion. As if an Officer will take more for his Fees than he ought, this is done colore officii sui, but yet it is not Part of his Office, and it is called Extortion, which is no other than Robbery, but it is more odious than Robbery, for Robbery is apparent, and always hath the Countenance of Vice, but Extortion, being equally as great a Vice as Robbery, carries the Mask of Virtue, and is more difficult to be tried or discerned, and consequently more odious 


\section{than Robbery.}

Ruff, supra note 19, at 1179-80 (footnotes omitted).

Ruff's first sentence merely quotes Blackstone, whose definition contains no demand requirement, no initiation requirement, and no coercion requirement. Further, the definition is broad enough on its face to cover noncoercive bribery behavior, because bribery is an unlawful taking, by color of office, of property not due the officer.

Ruff's second sentence discusses a Roman statute, which Ruff's footnote makes clear forbade all gifts, whether given voluntarily, or under duress.

The third sentence quotes chapter 26 of the First Statute of Westminster, which was the main English extortion statute for most of the last 700 years and which was frequently said to be merely declarative of the common law. It covers taking a reward to do one's office and says nothing about a demand, inducement, or coercion. Within a few decades of Westminster $I$, it was made clear that taking a reward not to do one's office was also extortion. The legislative history of the statute also indicates that it was intended to get at bribery behavior. Further, Ruff says that this basic extortion statute was a "comparable offense" to the Roman statute, a law that prohibited gifts, whether voluntary or coerced. See Statute of Westminster I, 3 Edw. I, c. 26 (1275); see also 3 COKE, FIRST INSTITUTE, supra note 120, at 541; 3 J. CHITTY, A PRACTICAL TREATISE ON THE CRIMINAL LAW 293 n.w (1832); Lindgren, supra note 4, at 841-48 (discussing origins of statute); 5 YEAR BOOKS OF EDWARD II, 1 THE EYRE OF KENT, 6 \& 7 EDWARD II 143 (F. Maitland et al. eds., 1910) (reporting inquest of 1313-14).

Ruff's fourth sentence incorrectly states that this section of Westminster I is still in force, but the citation in his footnote correctly lists the statute as repealed in 1968.

Ruff's fifth sentence introduces the Dive case from 1550. Dive v. Maningham, 1 Plowd. 60, 75 Eng. Rep. 96 (C.B. 1550).

The sixth and seventh sentences are mostly a quotation from Dive. Dive is often cited but seldom understood. See supra notes 133-36. First, Ruff incorrectly states that Dive is the earliest reported decision interpreting the extortion provision of Westminster I. On the contrary, Dive never mentions Westminster I, but rather concerns itself with a later extortion statute. See 23 Henry 6, c. 10 (1444). Second, Dive is not an extortion case, but instead an action on a bond. Third, the extortion statute in Dive was described in the opinion itself as having been designed to prevent "bribery." A statute that prevents bribery would not normally be limited to situations of demands, coercion, or initiation by the official. Fourth, the behavior called extortion in the case appears to be behavior that we would today also call bribery. A sheriff accepted a bond to let a prisoner out on bail when he was required by law to keep him in jail. The prisoner got more than fair treatment in return for a promise to pay. Fifth, the case says nothing about a demand requirement or about an initiation requirement.

While the case doesn't say that extortion is coercive, in obviously hyperbolic dicta it does liken extortion to robbery. But this doesn't distinguish extortion from bribery because particularly at the time, bribery was also likened to robbery. Indeed, in the OXFORD ENGLISH DICTIONARY [hereinafter OED] the first definition of the noun bribe is "theft, robbery." 1 OXFORD ENGLISH DICTIONARY 1092 (1st ed. 1928). The first definition of the verb bribe is "to steal, rob; to obtain by . . extortion; to extort." 1 OXFORD ENGLISH DICTIONARY 1092 (1st ed. 1928). The OED gives an example from 1461 tying together robbery, bribery, and color of office: "To lette brybers that wold a robbed a ship undyr color of my Lord of Warwyk." Id. Because the crime of bribery was just being created in the mid-1500s and it appears not to have applied to administrative officials then, the comparison with robbery perhaps was intended to 
Justice Thomas also cites John Noonan's Bribes as if it were a competing history of extortion. Noonan's monumental 839-page book is even less of a legal history of extortion than Ruff's. In fact, I could find only five sentences in the book discussing the history of extortion at common law. ${ }^{145}$ Noonan cites three authorities

make it easier to punish bribery behavior as extortion.

Thus the judicial speechifying in Dive wasn't meant to distinguish extortion from bribery. Everything said about extortion in Dive is consistent with bribery and extortion being overlapping crimes committed without coercion or demand. The only thing that could have been called coercive in Dive was that the sheriff would have kept the prisoner in jail where he belonged if his brother hadn't promised to pay a bribe to get out of jail. Dive is evidence that at common law bribing a jailer was extortion.

Ruff's brief history of common law extortion doesn't make any sweeping conclusions about demand, initiation, or coercion. In fact, if he hadn't made other statements later in his article, I couldn't have guessed where he stood on the supposed coercion requirement, demand requirement, or the bribery-extortion overlap. His history of common law extortion doesn't cite a single actual extortion case. The four authorities Ruff discusses in text all support the inclusion of bribery behavior within extortion and use language that is broad enough to cover the passive receipt of a bribe as extortion. Neither Ruff, nor any authority he cites in his history, says that extortion at common law required a demand, initiation, or coercion.

Yet, Ruff criticizes Judge Minton for arguing that at common law "color of public office took the place of the force, threats, or pressure implied in the ordinary meaning and understanding of the word extortion." Ruff, supra note 19, at 1182, quoting United States v. Sutter, 160 F.2d 754, 756 (7th Cir. 1947). Ruff says that Minton's explanation is "wholly at odds with the true common law origins of the offense." Id. What true origins? Ruff never says. He fails to explain the problem with Minton's statement. Nothing Ruff said earlier about common law extortion was in conflict with Minton's characterization. His handful of common law historical authorities point in the opposite direction from his oblique criticism of Minton.

145 John Noonan's Bribes contains only five sentences on the history of extortion at common law. (1) "Extortion would have required a showing of coercion which the managers of the impeachment [of Warren Hastings] did not attempt." NoONAN, supra note 6, at 398 (referring to the Warren Hastings case). (2-3) "At the core of [Stern's] article was the contention that 'extortion' under color of official right was equivalent to bribery. Blackstone's definition of extortion, he asserted, supported this position." Id. at 585 (citing Stern, supra note 19, at 14-15). (4) "Stern's contention that Blackstone supported his interpretation was substantively inaccurate." NOONAN, supra at 586. (5) "[T] he court in Kenny ignored Blackstone." Id. (referring to United States v. Kenny, 462 F.2d 1205 (3d Cir.), cert denied, 409 U.S. 914 (1972)).

The first sentence says that extortion required coercion, but he cites no support and the Hastings indictment itself equated bribery with extortion, a fact that prompted Noonan's contrary claim.

The second and third sentences merely describe Stern's claims, which supported the overlap of bribery and extortion. Noonan's fourth sentence says that Blackstone didn't support Stern, but Noonan doesn't explain why. Contrary to the implications of Noonan's claim, Blackstone describes extortion in language that seems to embrace bribery behavior and says nothing about coercion, a demand requirement, or an initiation requirement. The fifth sentence likewise says that the Kenny case ignored Blackstone but doesn't explain why Kenny and Blackstone are inconsistent. The 
with whom he disagrees because they treat bribery behavior as extortion, but these authorities all undercut his position. ${ }^{146} \mathrm{He}$ offers no affirmative support for his view that extortion at common law was limited to coercion.

Further, despite the fact that Bribes is the only significant history of bribery and one of the best criminal histories ever written, Noonan's social and literary history is generally much stronger than his legal analysis. Noonan's blind spot on extortion mars what is otherwise a great book. It causes him to miss the fact that the first English bribery statutes are really offshoots of extortion (i.e., extortion statutes that apply to judges), to argue incorrectly that "color of office" wasn't part of bribery, to misunderstand one of his main cases (the Warren Hastings case), to miss by at least 500 years the first clear prosecutions of bribery behavior by administrative officials, ${ }^{147}$ and to mischaracterize the modern Hobbs Act dispute.

interesting thing about these statements is that they are all really disagreements with the authorities being discussed. Noonan is saying that the Hastings case, Stern, and the Kenny case were wrong to include bribery behavior within the crime of extortion. $\mathrm{He}$ is disagreeing with the authorities he is presenting-certainly a historian's prerogative. But where is the positive proof that extortion was as Noonan says it was, not as the authorities he cites say it was? Far from supporting Noonan's opinions, the authorities discussed actually point in the opposite direction. He says they are wrong. But why? In Bribes, he never says.

That's Noonan's brief competing history of common law extortion. No common law extortion cases are mentioned. The only old case mentioned is Hastings, which is a case strongly showing the overlap of bribery and extortion. Noonan discusses Hastings as if it were a bribery case, but he admits that the charge was actually "extortion," not bribery. See NOONAN, supra note 6, at 398.

${ }^{146}$ See NOONAN, supra note 6 , at $398,585 \& 586$.

${ }^{147}$ See Lindgren, supra note 4, at 858-61 (discussing dozens of thirteenth-century cases charging or punishing bribery behavior by administrative officials, mostly as extortion). Noonan argued: "In 1600 only judges and witnesses could be criminally bribed, that is, found guilty of a crime for taking money to be influenced. By the eighteenth century the impeachment of Warren Hastings at least acknowledged that administrators fell within a class that could commit the crime." NOONAN, supra note 6 , at 579. In the particular charge Noonan discusses at length, however, Hastings was prosecuted for extortion, not bribery (as Noonan himself notes). See HOUSE OF COMMONS, Articles of Impeachment, in HOUSE OF LORDS SESSIONAL PAPERS 1794-1795, at 34-36 (F. Torrington ed., 1974). 


\section{The Quid Pro Quo Requirement}

In McCormick, Justice White announced an explicit quid pro quo requirement in campaign contribution cases $^{148}$ and was silent about corrupt intent, perhaps under the mistaken belief that the quid pro quo requirement could supplant an inquiry into corruption. In Evans, Justice Stevens extended a watered-down version of the quid pro quo requirement to all official extortion under the Hobbs Act, ${ }^{149}$ and Justice Kennedy emphasized the necessity of corrupt intent. ${ }^{150}$ Although the differences in language between McCormick and Evans are subtle, their practical effect is stark. I believe that, whereas the Stevens and Kennedy approaches are workable, Justice White's explicit quid pro quo requirement is not.

\section{Justice White's Explicit Quid Pro Quo Requirement}

One problem with Justice White's approach is its literalness. If you can prove a quid pro quo beyond a reasonable doubt, why should you also have to prove beyond a reasonable doubt that the quid pro quo is explicit? Why have a formalities requirement for extortion like a will or a deed of land? In wills and deeds, having a requirement of explicitness channels people to make their deals more explicit, ${ }^{151}$ channeling behavior in socially useful ways. In addition, exchangers already have an incentive to make deals explicit in order to make them enforceable in court. But in the criminal law, explicitness channels criminals to make their deals less explicit, channeling behavior in socially detrimental ways. Even without Justice White's innovation, the incentives already lead crooks to make their deals less explicit, since enforcement in court is never desired. Justice Kennedy insightfully argues:

The official and the payor need not state the quid pro quo in express terms, for otherwise the law's effect could be frustrated by knowing winks and nods. The inducement from the official is criminal if it is express or if it is implied from his words and

148 See McCormick v. United States, 111 S. Ct. 1807, 1815 (1991).

149 See Evans v. United States, 112 S. Ct. 1881, 1889 (1992).

${ }^{150}$ See id. at 1892 (Kennedy, J., concurring).

151 See Lon L. Fuller, Consideration and Form, 41 Colum. L. REv. 799, 801-03 (1941) (recognizing the channeling function); John H. Langbein, Sunstantial Compliance with the Wills Act, 88 HARv. L. REv. 489, 493-94 (1975) (discussing the channeling function); James Lindgren, Abolishing the Attestation Requirements for Wills, 68 N.C. L. REV. 541, 544 (1990) (same). 
actions, so long as he intends it to be so and the payor so interprets it.

The criminal law in the usual course concerns itself with motives and consequences, not formalities. And the trier of fact is quite capable of deciding the intent with which words were spoken or actions taken as well as the reasonable construction given to them by the official and the payor. ${ }^{152}$

Justice White's explicitness requirement is perverse and isn't directly mentioned in the Evans case.

Justice White seems to think that corrupt officials act like the killers in movie and television murder mysteries. In the last few minutes of most hack mysteries, the villain pauses before murdering the clever detective to explain to the detective how and why he killed; this pause not only allows the detective to escape the killer's evil clutches, but it makes explicit to the audience what happened. But in government corruption, only idiots or targets of government stings are likely to make things explicit. That's not how things are usually done. ${ }^{153}$ As Noonan notes, "[d]ealing with intelligent donees, the donor may reasonably expect a better return if he is not specific." $" 154$

Justice White commits what I call the Lawyer's Fallacy, ${ }^{155}$ named by analogy to the Psychologist's Fallacy and the Historian's Fallacy. The Lawyer's Fallacy assumes that people understand what they do, while they do it, from the perspective of a lawyer or that people act as if they are creating evidence for lawyers to find later. It sees people cooperatively climbing into pigeonholes where lawyers can easily find them.

\section{The Stevens Approach to the Quid Pro Quo Requirement}

Except when detailing the defendant's claim, Justice Stevens's majority opinion in Evans mentions a quid pro quo requirement in only one paragraph, where it also sets out its summary of the law of the case:

We reject petitioner's criticism of the instruction, and conclude that it satisfies the quid pro quo requirement of McCormick v. United States . . . because the offense is completed at the

152 Id.

153 Prosecutors have long pointed out the subtlety of public officials' shaking down citizens. See supra note 19.

154 NoONAN, supra note 6 , at 687.

155 See James Lindgren, The Lawyer's Fallacy, 68 CHI.-KENT L. REV. 109 (1992). 
time when the public official receives a payment in return for his agreement to perform specific official acts; fulfillment of the quid pro quo is not an element of the offense. We also reject petitioner's contention that an affirmative step is an element of the offense of extortion "under color of official right" and need be included in the instruction. As we explained above, our construction of the statute is informed by the common-law tradition from which the term of art was drawn and understood. We hold today that the Government need only show that a public official has obtained a payment to which he was not entitled, knowing that the payment was made in return for official acts. ${ }^{156}$

Is this a quid pro quo requirement or not? Justice Thomas's dissent characterizes it as such, but Justice Kennedy's concurrence treats the majority opinion as presenting the quid pro quo as "an alternative rationale." 157 Although the quid pro quo requirement is mentioned and the McCormick case is harmonized, I believe that a jury instruction following Evans should be based on the last sentence, rather than the words quid pro quo. Note that the language doesn't require any actual agreement or intent to take any official act; what's required is the receipt of a payment knowing it was made in return for official acts. At several points in his discussion, Justice Stevens describes extortion as corrupt, but he doesn't make that element a clear part of his analysis.

\section{The Kennedy Approach to the Quid Pro Quo Requirement}

Justice Kennedy argues for a position similar to Justice Stevens's, but he embraces a slightly stronger quid pro quo element:

Although the Court appears to accept the requirement of a quid pro quo as an alternative rationale, in my view this element of the offense is essential to a determination of those acts which are criminal and those which are not in a case in which the official does not pretend that he is entitled by law to the property in question.

-...

The requirement of a quid pro quo means that without pretense of any entitlement to the payment, a public official violates $\S 1951$ if he intends the payor to believe that absent payment the official is likely to abuse his office and his trust to the detriment and injury of the prospective payor or to give the prospective payor

${ }^{156}$ Evans v. United States, 112 S. Ct. 1881, 1889 (1992) (emphasis added).

${ }^{157}$ Id. at 1892 (Kennedy, J., concurring). 
less favorable treatment if the quid pro quo is not satisfied. The official and the payor need not state the quid pro quo in express terms.... ${ }^{158}$

Justice Kennedy also argues that "motive is crucial"159 and that "a public official who labors under the good-faith but erroneous belief that he is entitled to payment for an official act does not violate the statute. ${ }^{n 160}$

\section{Quid Pro Quos Aren't Necessarily Corrupt}

I suspect that most of the continuing difficulties in the use of the Hobbs Act against public corruption will stem from two sources: (1) How explicit must the understanding be?; and (2) What should be done about quid pro quos that may not be corrupt enough to be called extortion?

The problem that the Court is trying to solve is that elected officials often receive contributions from people with pending government business. Such contributions aren't necessarily corrupt. The old way to separate corrupt takings from noncorrupt contributions was to ask the ultimate question: Are they corrupt or wrongful? It appears that the Court thinks that a quid pro quo requirement does the same job separating wrongful takings from legitimate contributions. But does it?

Consider these explicit quid pro quos that aren't corrupt (or at least aren't corrupt enough to count as official extortion):

(1) A legislator says to a trucking company owner, "If you make this large contribution to my campaign, I promise you three things. First, I won't vote on any trucking legislation without calling you first. Second, when you call me, I will drop whatever official business I am doing to take your call personally. Third, when you or your clients come to town, I will rearrange my schedule whenever possible to entertain you in the legislative dining room. I can't promise you how I'll vote, but you can buy what any large contributor buys: direct access to me."

(2) A legislator says to a large contributor, "If you give me a large contribution, I'll consult you on my choice of my next chief of staff. Understand me, he'll be working for me, not you. But I promise you that I'll pick someone you can work with."

158 Id.

159 Id. at 1893 (Kennedy, J., concurring).

${ }^{160}$ Id. at 1894 (Kennedy, J., concurring). 
The contributor gets an explicit quid pro quo-access to the legislator or consultation on a staff appointment. Someone with very high ethical standards may view these last two examples as corrupt, but the Supreme Court probably wouldn't. Indeed, the legislators' willingness to state the deals clearly suggests that they wouldn't think they are corrupt. Yet both situations might meet Justices White's, Stevens's, and Kennedy's reciprocity tests, at least without a specific filter that the agreements be corrupt. Only by bringing in the corrupt intent element mentioned by Justice Stevens and embraced by Justice Kennedy can a jury make sense of these examples. Thus, if these examples don't involve obtaining property corruptly or wrongfully, even an explicit quid pro quo isn't enough for extortion.

But then, what does the explicit quid pro quo requirement add other than noise? If one must test extortion by whether it's corrupt in any event, a reciprocity requirement only adds another layer that may exculpate those otherwise guilty of wrongful extortion. The nature of the exchange must be examined in any event.

The obvious objection to relying on the corruption requirement alone is its vagueness. A quid pro quo requirement will give better notice than a simple corruption requirement. Anytime you're dealing with behavior as complex as promises and threats, you can't nail down every possible permutation in advance. The best approach is to use judicial decisionmaking to clarify ambiguities and give guidance to triers of fact. Evans does this by requiring reciprocity.

The Court of Appeals for the Fourth Circuit tried a softer, more nuanced approach in its McCormick opinion. ${ }^{161}$ It set out these criteria for distinguishing a corrupt campaign contribution from extortion:

Some of the circumstances that should be considered in making this determination include, but are not limited to, (1) whether the money was recorded by the payor as a campaign contribution, (2) whether the money was recorded and reported by the official as a campaign contribution, (3) whether the payment was in cash, (4) whether it was delivered to the official personally or to his campaign, (5) whether the official acted in his official capacity at or near the time of the payment for the benefit of the payor or supported legislation that would benefit the payor, (6) whether the

161 McCormick v. United States, 896 F.2d 61, 66 (4th Cir. 1990), rev'd, 111 S. Ct. 1807 (1991). 
official had supported similar legislation before the time of the payment, and (7) whether the official had directly or indirectly solicited the payor individually for the payment. ${ }^{162}$

In particular, large cash payments not properly recorded are a tipoff that something is very likely wrong. The Supreme Court in McCormick rejected these criteria, ${ }^{163}$ although they seem fairly sensible. Certainly, they're preferable to McCormick's perverse explicitness requirement. In Evans, the Court has moved away from an explicit quid pro quo to a much less strict reciprocity requirement. While not required by the legislative history of the Hobbs Act or the common law history of extortion, Evans' reciprocity requirement does limit the statute to the most common and easily prosecuted form of serious corruption: "a public official [who] has obtained a payment to which he was not entitled, knowing that the payment was made in return for official acts. ${ }^{\text {164 }}$

\section{CONCLUSION}

Occasionally over the last 150 years, lawyers have tried to distinguish bribery and extortion in some way that would keep the two crimes entirely separate. But at almost every turn, they have been thwarted-with good reason. The overlap of bribery and extortion can be accounted for theoretically, historically, and pragmatically.

The theoretical overlap between bribery on the one hand, and blackmail and extortion on the other, becomes clear if one adopts my theory of blackmail. Both crimes involve the misuse of a representative power for personal gain-even if that representative power is not always formalized in blackmail situations. When someone threatens a prostitute to cause her to be arrested unless she pays the threatener to keep quiet, it matters little to the law of blackmail or extortion whether the threatener is a private citizen or a public official. Either would be using fear of the state and the public (i.e., state or public leverage) for personal gain. If either received a payoff not to testify or prosecute, he would also be guilty of receiving a bribe. Again, he would be trading on state leverage for personal gain. In my view, both bribery and blackmail are grounded in a similar wrong.

$162 I d$. at 66.

163 See McCormick, 111 S. Ct. at 1807.

164 Evans v. United States, 112 S. Ct. 1881, 1889 (1992). 
The historical overlap arose because the crime of bribery developed relatively late, perhaps not being routinely applied to administrative officials until the 1800 s. Since the 1200 s extortion filled the gap, covering acquisitions by bribery behavior, false pretenses, and coercion. The first English statutes that later were considered bribery statutes were essentially extortion statutes that applied to judges. Bribery was thus an offshoot of extortion, and most bribery situations remained within the sphere of official extortion at common law. Roughly, bribery involved payments that were corrupt to make (and to receive), while extortion involved payments that were corrupt to receive.

The pragmatic benefit of recognizing an overlap can be gleaned from looking at the parts of the story already told-the theory and the history. If one adopts some unwise distinction, such as that bribery is voluntary while extortion is coercive or that in bribery the citizen makes the first approach, it's exceedingly difficult for a judge, jury, or prosecutor to know how to separate the crimes. Most payoff situations involve both a threat of the possibility of worse than fair treatment (core extortion) and the promise of unfairly positive treatment (core bribery). The bribery-extortion distinction is not a typical case of difficult legal line-drawing. Bribery and extortion don't approach each other at their edges. They overlap at their cores.

Where the law or fairness doesn't require separating the two crimes for public officials, it's not practical to do so. The historical meanings should be respected and the courts should try to proceed to clarify the crimes so as to give defendants fair notice of what's prohibited. That's what the Court seems to be doing with its opinion in Evans: bribery and extortion overlap; no act of inducement is required; and the Government "need only show that a public official has obtained a payment to which he was not entitled, knowing that the payment was made in return for official acts. ${ }^{165}$

A discordant note is sounded in Justice Thomas's dissenting opinion in Evans. Not only does Justice Thomas angrily accuse his colleagues of making up the law, ${ }^{166}$ but he argues that it was settled law that official extortion was limited to a pretense that the payment was owed. As Justice Stevens points out, however, Justice Thomas is unable to come up with a single case where an official

165 Id. ing text.

${ }^{166}$ See id. at 1897 (Thomas, J., dissenting); see also supra note 68 and accompany- 
was found innocent of official extortion because he didn't trick the citizen into paying. ${ }^{167}$ Justice Thomas has clearly misread most of the cases he cites. In two of these cases, ${ }^{168}$ the court explicitly rejected Justice Thomas's argument, holding that a pretense of official entitlement was not required for official extortion.

Justice Thomas further argues that what distinguishes extortion from bribery is that extortion required a taking under "color of office," while bribery didn't. In particular, he complains about the Evans majority's heavy reliance on my work and claims that I fail to account adequately for the "color of office" requirement. ${ }^{169}$ Although in an earlier article, I had given considerable evidence of the meaning of color of office at common law, I had mentioned only in passing its role in bribery cases. ${ }^{170}$ Yet, since the Hobbs Act debate arose in 1972, no judge or academic commentator had claimed that official extortion was limited to false pretenses-until Justices Scalia in McCormick and Thomas in Evans. In this Article, I show that from the earliest discussions of the crime of bribery in the common law treatises (Coke and Hawkins) through the twentieth century, bribery has been understood as a "color of office" offense. Indeed, takings by color of office refer to the core of bribery behavior, payments to distort official action. Color of office has been called "the essence of the crime" of bribery. ${ }^{171}$ Rather than distinguishing extortion from bribery, the traditional "color of office" language links the two offenses.

For as long as there have been governments, there has been corruption. To prosecute corruption fairly, legislatures and courts must give notice of what's prohibited and what's not. In Evans, the United States Supreme Court has gone a long way toward settling an interpretive problem that has plagued American extortion jurisprudence for over a century. But let's not fool ourselves: the debate is not over. It will merely shift from those questions that are newly answered to the remaining mysteries of the law of extortion.

167 See id. at 1890.

${ }^{168}$ Dean v. State, 71 S.E. 597, 598 (Ga. Ct. App. 1911); Hanley v. State, 104 N.W. 57 (Wis. 1905).

${ }^{169}$ Evans, 112 S. Ct. at 1895 (Thomas, J., dissenting).

${ }^{170}$ Lindgren, supra note 133.

171 State v. Hendricks, 186 P.2d 943, 947 (Ariz. 1947) (quoting 1 BuRdICK, LAW OF CRIME § 291). 